\title{
Analytical Solutions for Girder Distribution Factor in Steel-Concrete Composite Girders with the Effect of Parapets
}

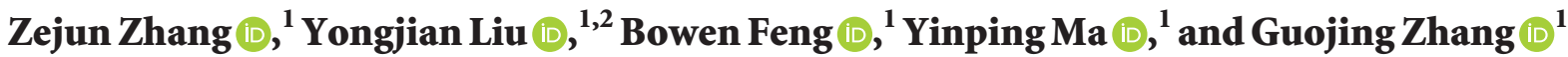 \\ ${ }^{1}$ School of Highway, Chang'an University, Xi'an 710064, China \\ ${ }^{2}$ Research Center of Highway Large Structure Engineering on Safety, Ministry of Education, Chang'an University, \\ Xi'an 710064, China \\ Correspondence should be addressed to Yongjian Liu; liuyongjian@chd.edu.cn
}

Received 7 June 2021; Revised 12 August 2021; Accepted 9 September 2021; Published 26 September 2021

Academic Editor: DongDong Ge

Copyright (c) 2021 Zejun Zhang et al. This is an open access article distributed under the Creative Commons Attribution License, which permits unrestricted use, distribution, and reproduction in any medium, provided the original work is properly cited.

\begin{abstract}
The existing studies have shown that parapets have great influence on the girder distribution factor (GDF) of bridges. However, there is no method in the design guide to estimate the GDF considering the effect of parapets. This research aims to develop a simplified method for estimating the GDF by considering the effect of parapets. First, a simply supported steel-concrete composite girder bridge was tested to investigate the effect of parapets on the GDF. Then, finite-element (FE) model was established and verified by the field test data of strain and deflection. In addition, error study showed that the bending stiffness of the bridge was increased by about $92 \%$ and $19.1 \%$, respectively, due to the effects of parapet and continuous layer. As the effect of the continuous layer on each girder was relatively uniform, the simplified method was optimized only considering the effect of the parapet. Finally, the effect of the parapet on the GDF was compared and discussed. Considering the effect of the parapet, the GDF of the exterior girder calculated by the simplified method and FE analysis decreased by about $26.92 \%$ and $23.53 \%$, respectively, and the adjacent interior girder decreased by about $15.22 \%$ and $12.77 \%$, respectively. Comparing the GDF calculated by the AASHTO LRFD specifications, the GDF calculated by the simplified method decreased by about $30.77 \%$ in the exterior girder and $41.30 \%$ in the interior girder, respectively. The results indicate that the method of calculating the GDF without considering the effect of the parapet in AASHTO LRFD specifications is conservative. The GDF calculated by the simplified method was basically close to the field test results, meaning that the proposed simplified method considering the effect of the parapet was relatively accurate.
\end{abstract}

\section{Introduction}

Girder distribution factor (GDF) of bridges has been broadly used to simplify the analysis of transverse effect caused by live loads since the 1930s and can be obtained by analytical methods, finite-element (FE) analyses, field tests, and laboratory tests.

"S-D" method in AASHTO Standard specification was used to calculate the GDF $[1,2]$. In this method, the GDF is linearly related to the spacing (S) of girders, while " $D$ " is a constant related to the type and geometric properties of the bridge [2, 3]. Before the 1990s, most investigations were focused on revising the parameter D by analytical methods or field tests [4-6]. After the 1990s, with the development of finite-element technology, Zokaie et al. [7, 8] investigated the influence parameters of the GDF by FE analysis and proposed the equations including span, spacing of girders, longitudinal stiffness of girders, and thickness of a concrete deck to calculate the GDF for moment of interior girders, while the GDF for moment of exterior girders was obtained based on the revision of equation for interior girders by the cantilever width of the deck. The GDF for shear of the interior girder was calculated by the "S-D" or lever rule method, and the GDF for shear of the exterior girder was also modified by the results of the interior girder. The equations were adopted by AASHTO LRFD specifications [9], and the GDF for moment of composite girder bridges with two or more lanes in interior girders was given by 


$$
\mathrm{GDF}_{\text {in }}=0.075+\left(\frac{S}{9.5}\right)^{0.6}\left(\frac{S}{L}\right)^{0.2}\left(\frac{K_{g}}{12.0 L t_{c}^{3}}\right)^{0.1}
$$

where $S$ is the girder spacing; $L$ is the span length; $K_{g}=$ $n\left(I+A e_{g}^{2}\right)$ is the longitudinal stiffness, in which $n$ is the modular ratio between steel and concrete, $I$ is the girder moment of inertia, $A$ is the girder area, $e_{\mathrm{g}}$ is the eccentricity between centroids of the steel girder and the deck; and $t_{\mathrm{c}}$ is the deck thickness. For simplification, Phuvoravan et al. [10] modified the GDF calculation method based on AASHTO LRFD specifications as

$$
\mathrm{GDF}=0.15+0.73 \frac{S^{0.8}}{L^{0.3}} e_{g}^{(L / 590)}
$$

Huo et al. proposed Henry's method [11] and modified it later $[12,13]$. The modified Henry method with two or more lanes for moment was given by

$$
\mathrm{GDF}=1.09\left(\frac{R W}{10 N_{g}}\right),
$$

where $R$ is the multiple presence factor; $W$ is the width of lanes; and $N_{\mathrm{g}}$ is the number of girders. Some investigations modified the GDF calculation methods of curved $[3,14,15]$ and skewed $[16,17]$ bridges based on AASHTO Standard specification and AASHTO LRFD specification.

However, it was found that these methods overestimated the GDF and underestimated the stiffness of the bridge [18-20]. The reason was that the methods ignored the contribution of secondary members, such as parapets [21-25]. Field tests also proved that the stiffness and capacity of bridges were larger than the predicted value by specifications [26-29].

Several researchers have investigated the effect of secondary members on the GDF of bridges, and some quantitative conclusions have been drawn. Mabsout et al. analysed 120 bridges to explore the influence of sidewalks and railings on the GDF by FE analyses [22] and field tests [23]. The results show that the exterior girder can resist more of the live load by considering the effects of sidewalks and railings; thereby, the load-carrying capacity of the bridge can be increased by about 30\%. Eamon and Nowak [24] investigated the effect of edge-stiffening elements and diaphragms on the GDF with a steel-concrete composite girder by FE analysis. The results suggest that the GDF can be reduced by about $10 \%$ to $40 \%$ in the range of elasticity by the secondary elements, while about $5 \%$ to $20 \%$ in the range of inelasticity. Conner and Huo [26] explored the effect of parapets on the GDF by comparing the results of FE analysis with the AASHTO standard and AASHTO LRFD specifications. The research shows that the GDF can be reduced by about $36 \%$ for exterior girders by the parapet and 13\% for interior girders. Chung et al. [27] investigated the effect of lateral bracing, parapets, and deck cracking on the GDF by FE analysis. The results show that the lateral bracing and parapets may decrease the GDF up to $40 \%$ lower than the AASHTO LRFD values. Longitudinal cracking may increase the GDF up to $17 \%$ than the AASHTO LRFD values, while the transverse cracking was not significantly influencing the GDF. Akinci et al. [30, 31] proposed a spring analogy method to predict the effect of parapets on steel-concrete composite girder bridges under overload vehicles by FE analysis. The research shows that the GDF can be reduced by about $30 \%$ by continuous parapets. Roddenberry et al. [29] investigated the effects of parapets on the GDF with a Florida Bulb-T girder bridge and an AASHTO Type-IV girder bridge by field tests. It was found that the parapet could decrease the strains in the exterior girder, and an expansion joint in the parapet caused a localized strain increasing in the exterior girder, while the joint had a small effect on the interior girder.

Although many researchers have investigated the effect of parapets on the GDF by FE analyses or field tests, there was no simplified method to estimate the GDF considering the effects of parapets. Obviously, field tests not only took a long time and costed a lot but also needed to be carried out after the bridge was built. FE analysis was easy enough to model girder bridges and was able to provide exact stress distribution to calculate the GDF; however, the simplified analysis method could more directly reflect the physical influence factors of the GDF, and the designers could better understand the mechanism of the simplified method and optimize the design. Therefore, the purpose of this paper was to develop a simplified method (optimization of the modified eccentric load method) to estimate the effect of parapets on the GDF. First, a simply supported steel-concrete composite girder bridge was tested to study the effect of parapets. Then the accuracy of the FE model was verified by the field test results. The error study was subsequently carried out to find the influence factors which caused the large stiffness of the bridge, so the modified eccentric load method was optimized according to the main influence factors. Finally, the GDF obtained by the simplified method, FE analysis, field test, and AASHTO LRFD specifications were compared and discussed.

\section{Field Test}

2.1. Tested Bridge. Figure 1 shows the general layout of the field test bridge. Figure 1(a) shows the elevation plan of the bridge. The total length of the bridge is $86 \mathrm{~m}$. -The superstructure of the bridge consists of four-span simply supported steel-concrete composite girders. The total length and span of each simply supported girder are $20 \mathrm{~m}$ and $19.4 \mathrm{~m}$, respectively. At abutments, there are two expansion joints in the bridge. At piers, the distance between adjacent span is $40 \mathrm{~mm}$, and there is a continuous layer with a length of $80 \mathrm{~m}$ above the deck. Figure 1(b) shows the cross section in midspan of the bridge. Materials of the steel girders, crossbeams, and stiffeners are all Q345qD steel. The spacing between the adjacent steel girders is $2.0 \mathrm{~m}$, and the depth of the steel girder is $0.90 \mathrm{~m}$. The size of top flanges, webs, and bottom flanges of the steel girder are $350 \mathrm{~mm} \times 18 \mathrm{~mm}$, $858 \mathrm{~mm} \times 16 \mathrm{~mm}$, and $400 \mathrm{~mm} \times 24 \mathrm{~mm}$, respectively. There are three cross-beams with a distance of $9.7 \mathrm{~m}$ along the longitudinal direction of the bridge. The depth of the crossbeam is $250 \mathrm{~mm}$. The size of flanges and webs of the cross- 


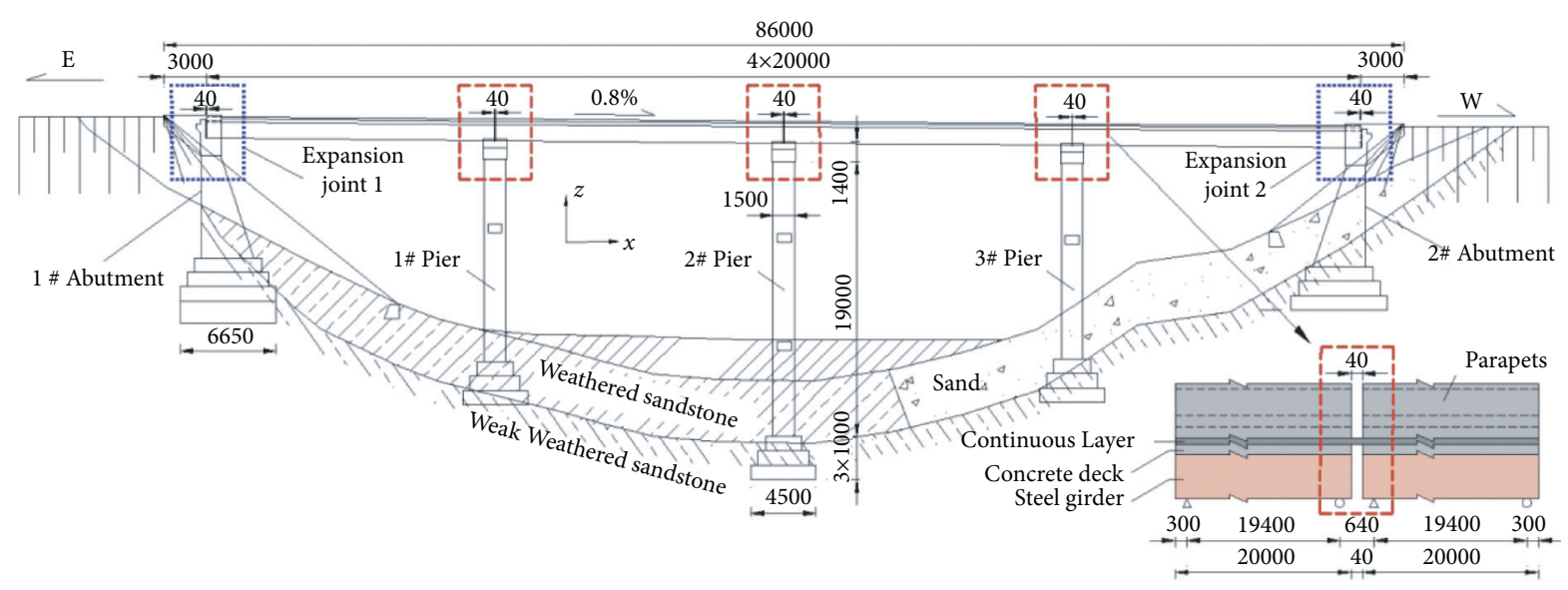

(a)

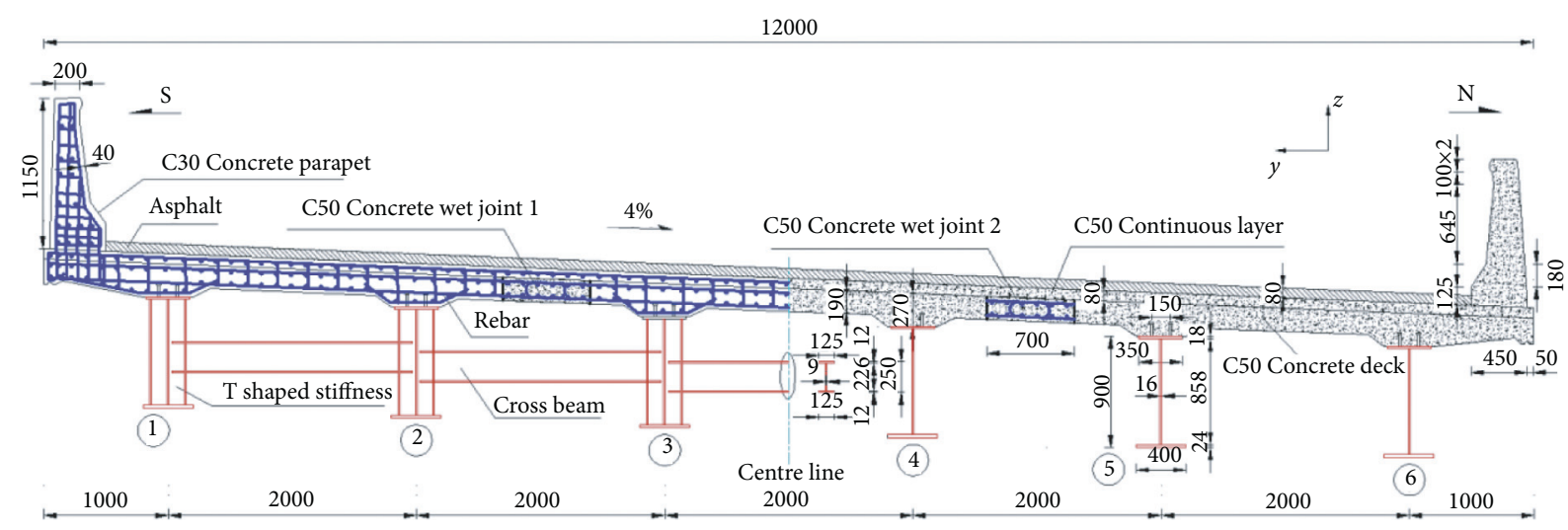

(b)

Figure 1: General layout of the field test bridge (unit: $\mathrm{mm}$ ): (a) elevation plan (b) cross section in midspan.

beams are $125 \mathrm{~mm} \times 12 \mathrm{~mm}$ and $226 \mathrm{~mm} \times 9 \mathrm{~mm}$, respectively. Materials of the deck and continuous layer are both C50 concrete, while the parapet is C30 concrete. The general thickness of concrete deck is $0.19 \mathrm{~m}$, while the enhanced part of the concrete deck near the steel girder is $0.27 \mathrm{~m}$. The depth and bottom width of the parapet are $1.15 \mathrm{~m}$ and $0.45 \mathrm{~m}$, respectively. As an anticollision structure, the parapet is continuous for the whole span of $20 \mathrm{~m}$. The steel girder and concrete deck are connected by shear studs to form the composite section. The height and diameter of shear studs are $12 \mathrm{~cm}$ and $22 \mathrm{~mm}$, respectively. The diameters of reinforcements in the concrete deck, continuous layer, and parapets are all $16 \mathrm{~mm}$.

2.2. Field Test Procedure. Figure 2 shows the axle weight and position of trucks in the field test. Four trucks, in order A, B, $\mathrm{C}$, and $\mathrm{D}$, were used to achieve four-step loading. The distance between rear axle and midrear axle is $140 \mathrm{~cm}$, while between front axle and midrear axle is $350 \mathrm{~cm}$. The lateral wheel spacing is $180 \mathrm{~cm}$. The total axle weight of the truck was kept in about $400 \mathrm{kN}$ with front axle of $80 \mathrm{kN}$ and rear axle and midrear axle of $160 \mathrm{kN}$. Table 1 shows the actual axle weight of the truck in the field test. The actual weight of each axle of the truck is little different from the required axle weight by the field test, and the actual total axle weight of each truck is basically kept at $400 \mathrm{kN}$. The distance between the inside edge of parapet and loading trucks of the outside edge was $50 \mathrm{~cm}$, and the distance between two trucks along lateral direction was $130 \mathrm{~cm}$. The distance between rear axles of two trucks along longitudinal direction was $500 \mathrm{~cm}$.

Figure 3 shows the position and layout of sensors on steel girders at the midspan cross section of the bridge. Seventytwo strain gauges of 120-3AA were arranged on the surface of six steel girders, and the number of strain gauges on the surface of the top flange, web, and bottom flange of each steel girder are 2, 6, and 4, respectively. Six dial gages of LINKS 030 were arranged at the bottom of the steel girders. Figure 4 shows the position and layout of sensors on the concrete deck and cross-beams at the midspan cross section of the bridge. Ten (number $1 \sim 10$ ) and 6 (number 11 16) strain gauges of 120-80AA along the longitudinal direction and lateral direction of the bridge were arranged at the bottom surfaces of the concrete deck between adjacent steel girders, respectively. Totally, 50 and 30 strain gauges of $120-80 \mathrm{AA}$ were arranged, respectively. Forty strain gauges of 120-3AA were arranged on the surface of five cross-beams, and the number of strain gauges on the surface of the top flange, web, and bottom flange of each cross-beam are 2, 4, and 2, respectively. 


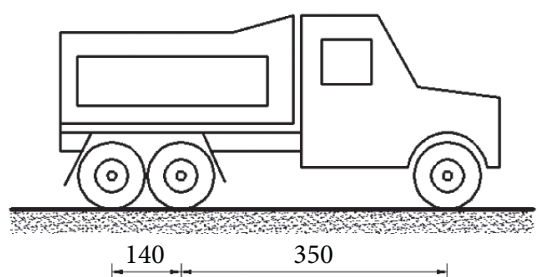

(a)

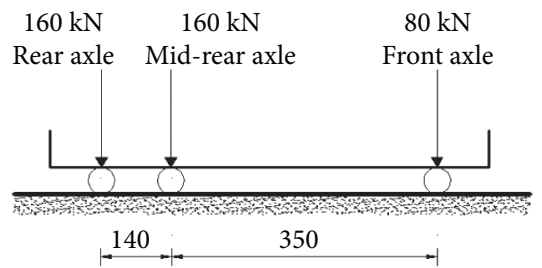

(c)

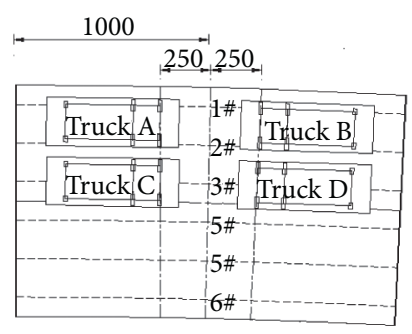

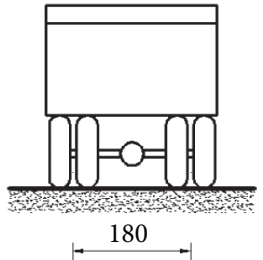

(b)

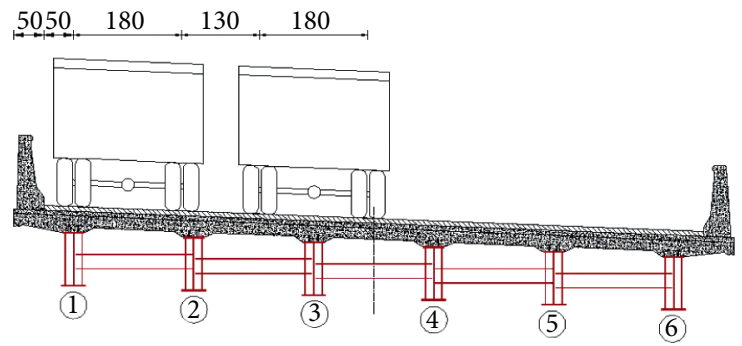

(d)

$1^{\text {st }}$ step loading: Truck A

$2^{\text {nd }}$ step loading: Truck A \& Truck B

$3^{\text {rd }}$ step loading : Truck A

\& Truck B

$\&$ Truck C

$4^{\text {th }}$ step loading : Truck A

$\&$ Truck B

\& Truck C

\& Truck D

(e)

FIgURE 2: Axle weight and position of trucks (unit: $\mathrm{cm}$ ): (a) axle distance; (b) lateral wheel spacing; (c) axle weight; (d) trucks position along lateral direction of the bridge; (e) trucks position along longitudinal direction of the bridge.

Table 1: Actual axle weight of the truck in the field test.

\begin{tabular}{|c|c|c|c|c|c|c|}
\hline \multirow[b]{2}{*}{$\begin{array}{l}\text { Truck } \\
\text { no. }\end{array}$} & \multicolumn{2}{|c|}{ Axle distance $(\mathrm{m})$} & \multicolumn{3}{|c|}{ Axle weight $(\mathrm{kN})$} & \multirow[b]{2}{*}{$\begin{array}{c}\text { Total axle weight } \\
(\mathrm{kN})\end{array}$} \\
\hline & $\begin{array}{l}\text { Rear axle to midrear axle } \\
\text { (m) }\end{array}$ & $\begin{array}{l}\text { Front axle to midrear axle } \\
(\mathrm{m})\end{array}$ & $\begin{array}{c}\text { Front axle } \\
(\mathrm{kN})\end{array}$ & $\begin{array}{l}\text { Midrear axle } \\
(\mathrm{kN})\end{array}$ & $\begin{array}{l}\text { Rear axle } \\
(\mathrm{kN})\end{array}$ & \\
\hline $\mathrm{A}$ & 1.4 & 3.5 & 82.2 & 153.2 & 158.4 & 393.8 \\
\hline B & 1.4 & 3.5 & 93.4 & 145.2 & 156.2 & 394.8 \\
\hline $\mathrm{C}$ & 1.4 & 3.5 & 87.4 & 149.5 & 164.5 & 401.4 \\
\hline $\mathrm{D}$ & 1.4 & 3.5 & 92.0 & 151.8 & 157.2 & 401.0 \\
\hline
\end{tabular}

Figure 5 is the photos of four-step loading of the field test. Before the field test, loading and unloading were applied 1 to 2 times to eliminate the inelastic deformation of the structure. Then strain gauges and dial gages were checked to ensure the equipment in normal working condition and set back to zero. When each truck reached the predetermined position, the engine was shut down. After all the data were stabilized, the strain data were collected and recorded by TDS 601, while the deflection data were read and recorded by field testers, as shown in Figure 6. The bridge was unloaded in the opposite sequence with the loading.

Table 2 is the result of the loading efficiency under the 4 th step loading. The positive bending moments in midspan under the field test loading and most unfavorable condition were $1420 \mathrm{kN} \cdot \mathrm{m}$ and $1316 \mathrm{kN} \cdot \mathrm{m}$, respectively. The impact factor was 1.117 , so the loading efficiency was 0.97 , meeting the requirements $(0.85 \sim 1.05)$ in the specification [32].

According to lot of experiments, the GDF of the $i$ th girder could be calculated by the ratio of strain [33] value or deflection [34] value of the $i$ th girder to the sum of strain values or deflection values of all girders as

$$
\begin{aligned}
& \mathrm{GDF}=\frac{\varepsilon_{i}}{\sum_{i=1}^{N_{g}} \varepsilon_{i}} \cdot N_{L}, \\
& \mathrm{GDF}=\frac{\Delta_{i}}{\sum_{i=1}^{N_{g}} \Delta_{i}} \cdot N_{L},
\end{aligned}
$$

where $\varepsilon_{i}$ is the maximum strain value of the bottom flange of the $i$ th steel girder; $N_{L}$ is the number of lanes; $N_{\mathrm{g}}$ is the number of girders; and $\Delta_{i}$ is the maximum deflection value 


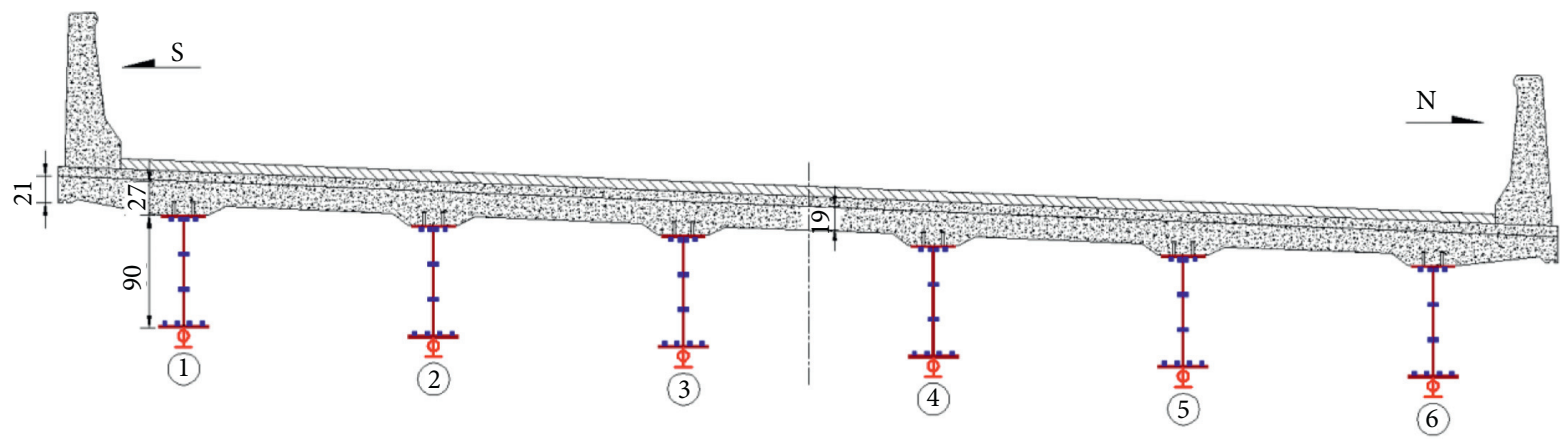

(a)

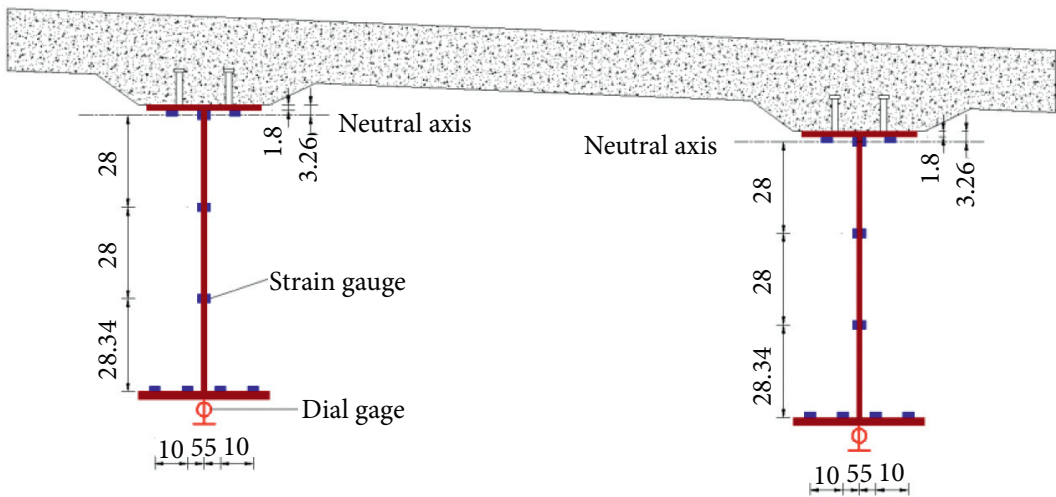

(b)

Figure 3: Position and layout of sensors on steel girder at the midspan cross section of the bridge (unit: $\mathrm{cm}$ ): (a) general layout and (b) detailed layout of strain gauges and dial gages.

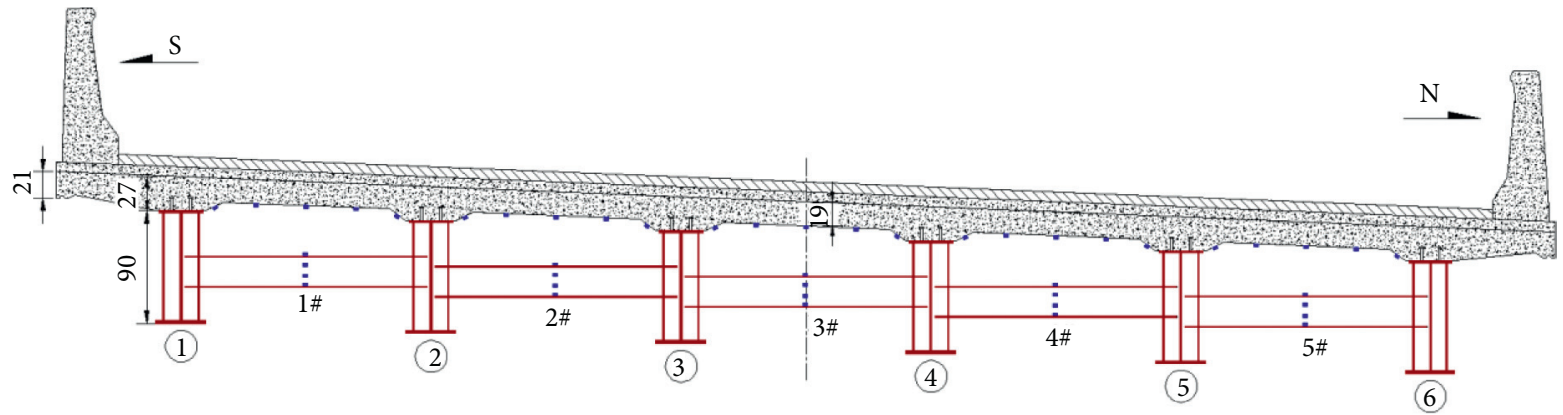

(a)

Profile of 1-1
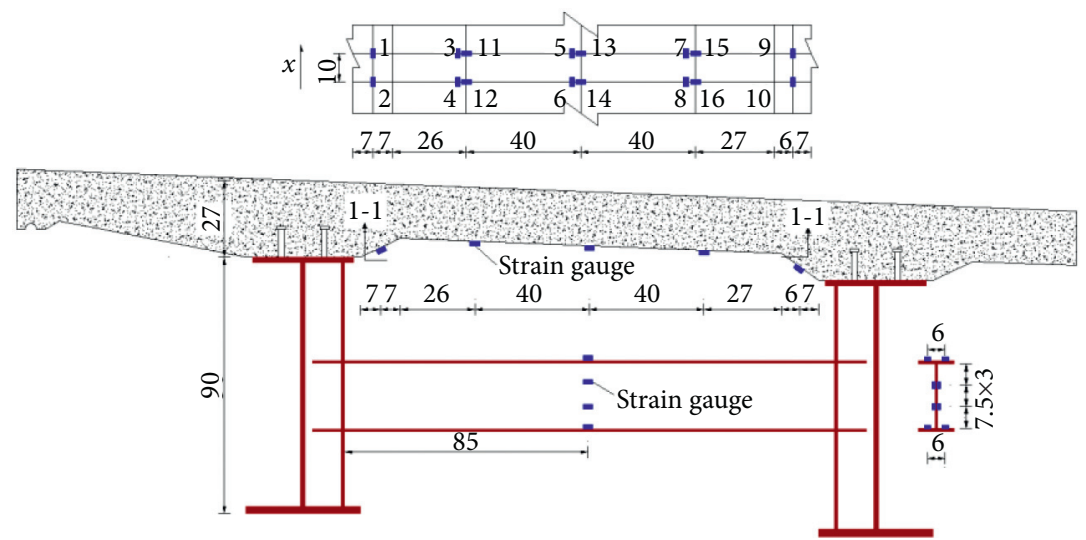

(b)

FIGURE 4: Position and layout of sensors on concrete deck and cross-beams at the midspan cross section of the bridge (unit: $\mathrm{cm}$ ): (a) general layout and (b) detailed layout of strain gauges. 


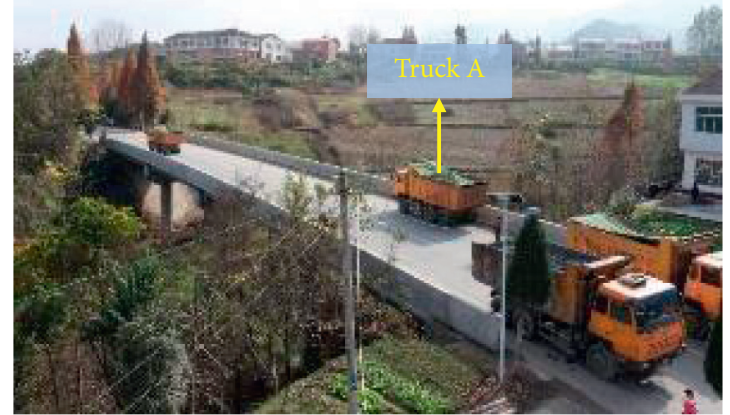

(a)

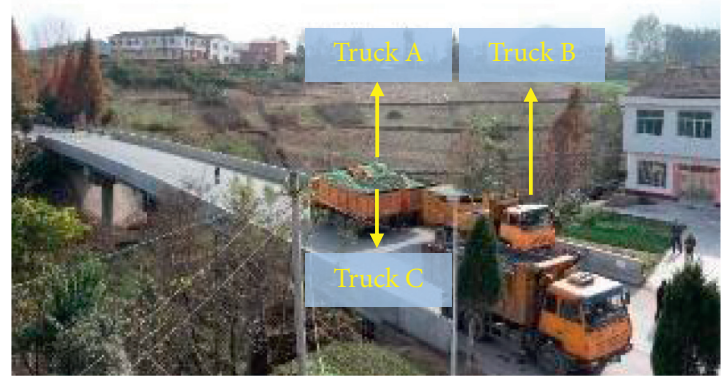

(c)

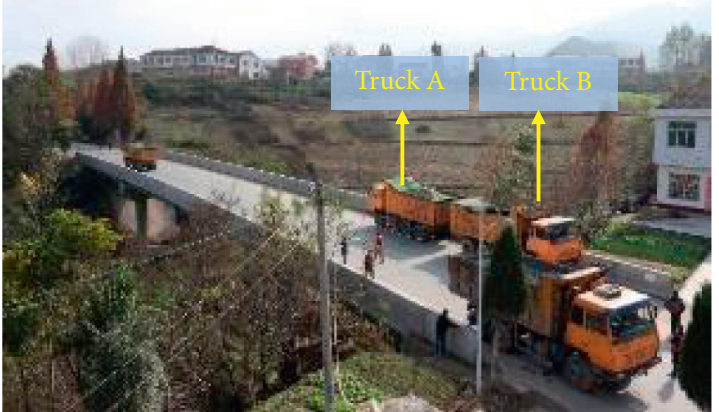

(b)

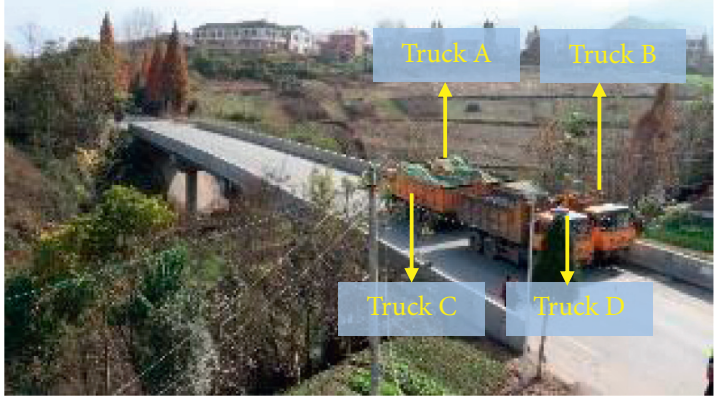

(d)

Figure 5: Step loading photos of field test: (a) first step loading; (b) second step loading; (c) third step loading; (d) fourth step loading.
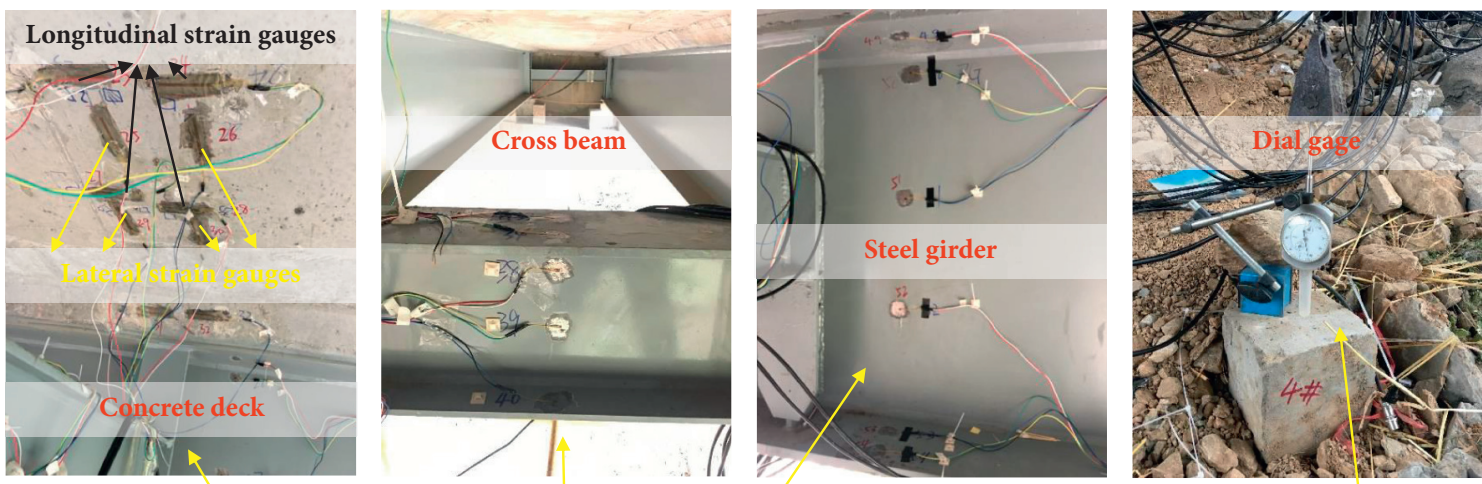

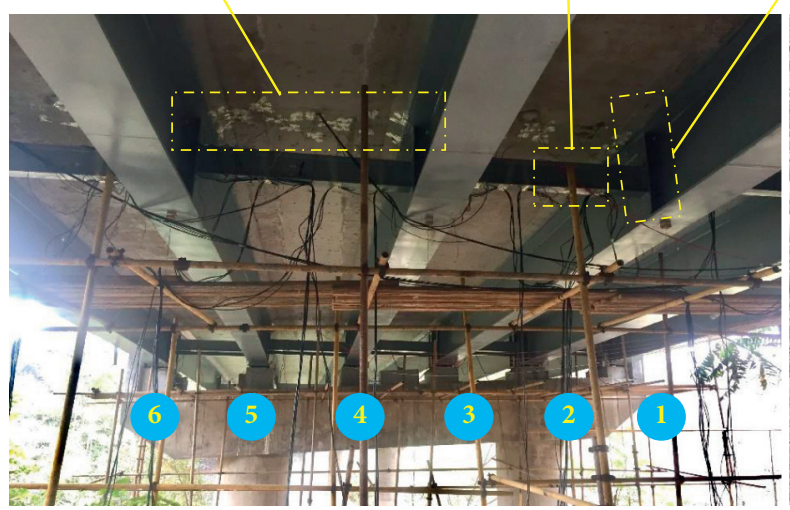

(a)

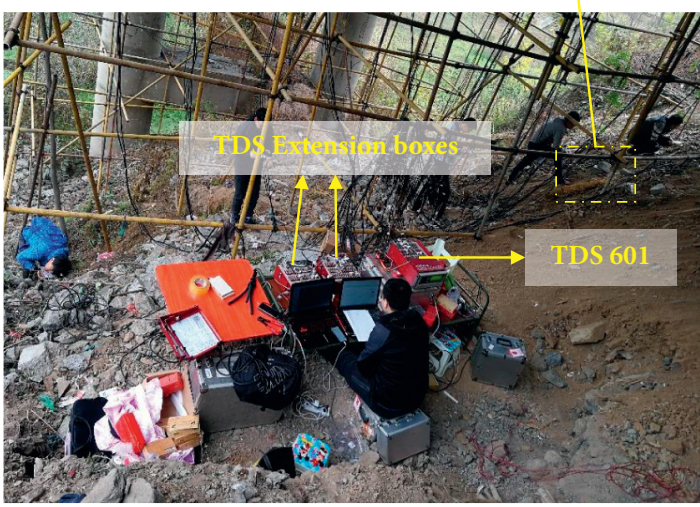

(b)

FiguRE 6: Field test: (a) strain gauge arrangement and (b) data collected and recorded. 
TABLe 2: Loading efficiency under the 4th step loading.

\begin{tabular}{|c|c|c|c|c|c|c|c|}
\hline \multicolumn{2}{|c|}{ Field test condition } & \multirow{2}{*}{$\begin{array}{c}\begin{array}{c}\text { Loading effect of } \\
\text { field test }(\mathrm{kN} \cdot \mathrm{m})\end{array} \\
1420\end{array}$} & \multirow{2}{*}{$\begin{array}{l}\text { The most unfavorable } \\
\text { condition }(\mathrm{kN} \cdot \mathrm{m}) \\
1316\end{array}$} & \multirow{2}{*}{$\begin{array}{c}\begin{array}{c}\text { Impact } \\
\text { factor }\end{array} \\
1.117\end{array}$} & \multirow{2}{*}{$\begin{array}{c}\text { Load efficiency } \\
0.97=1420 / \\
(1316 \times 1.117)\end{array}$} & \multirow{2}{*}{$\begin{array}{c}\begin{array}{c}\text { Field test } \\
\text { content }\end{array} \\
\begin{array}{c}\text { Stress and } \\
\text { deflection }\end{array}\end{array}$} & \multirow{2}{*}{$\begin{array}{c}\begin{array}{c}\text { Loading } \\
\text { type }\end{array} \\
\begin{array}{c}\text { Step } \\
\text { loading }\end{array}\end{array}$} \\
\hline $\begin{array}{l}\text { Eccentric } \\
\text { loading }\end{array}$ & $\begin{array}{l}\text { Positive bending } \\
\text { moment in } \\
\text { midspan }\end{array}$ & & & & & & \\
\hline
\end{tabular}

of the ith steel girder. Eom and Nowak [35] and Stallings and Yoo [36] modified the calculating equation of the GDF when the geometric properties of each girder are different as

$$
\begin{aligned}
\mathrm{GDF} & =\frac{M_{i}}{\sum_{j=1}^{N_{\mathrm{g}}} M_{j}} \cdot N_{\mathrm{L}}=\frac{E S_{i} \varepsilon_{i}}{\sum_{j=1}^{N_{\mathrm{g}}} E S_{j} \varepsilon_{j}} \cdot N_{\mathrm{L}}=\frac{S_{i} / S_{1} \varepsilon_{i}}{\sum_{j=1}^{N_{g}} S_{j} / S_{1} \varepsilon_{j}} \cdot N_{\mathrm{L}} \\
& =\frac{\varepsilon_{i} \omega_{i}}{\sum_{j=1}^{N_{\mathrm{g}}} \varepsilon_{j} \omega_{j}} \cdot N_{\mathrm{L}},
\end{aligned}
$$

where $M_{i}$ is the moment value of the $i$ th girder; $E$ is the elastic modulus of materials; $S_{i}$ is the section modulus of the $i$ th girder; $S_{1}$ is the section modulus of the typical interior girder; $\omega_{i}$ is the ratio of the section modulus of the $i$ th girder to the typical interior girder.

\section{FE Analysis}

ABAQUS 6.14 was used for FE analysis. Since the parapet was continuous for the whole span of $20 \mathrm{~m}$, the depth and longitudinal bending stiffness of the parapet are $1.15 \mathrm{~m}$ and $1.07 \times 10^{15} \mathrm{~N} \mathrm{~mm}^{2}$, respectively, while the composite girder are $1.17 \mathrm{~m}$ and $2.72 \times 10^{15} \mathrm{~N} \mathrm{~mm}^{2}$, respectively. The bending stiffness ratio of the parapet to the composite girder is about $39.34 \%$; therefore, the influence of the parapet could not be ignored.

3.1. Constitutive Relationship of Steel and Concrete. The constitutive relationship with the form of three-fold lines was used to represent the material properties of Q345qD steel, as shown in Figure 7 (a). The yield strength $f_{\mathrm{y}}$, design strength $f_{\mathrm{yd}}$, and ultimate strength $f_{\mathrm{u}}$ of steel are $345 \mathrm{MPa}$, $270 \mathrm{MPa}$ and $580 \mathrm{MPa}$, respectively. The elastic modulus $E_{\mathrm{s}}$ is $206,000 \mathrm{MPa}$. The yield strain $\varepsilon_{\mathrm{y}}$ is $1.2 \mathrm{f}_{\mathrm{y}} / E_{\mathrm{s}}$. The maximum strain $\varepsilon_{\mathrm{t}}$ of flat line is $10 \varepsilon_{\mathrm{y}}$, and the ultimate strain $\varepsilon_{\mathrm{u}}$ is $100 \varepsilon_{\mathrm{y}}$.

Figure 7(b) shows the constitutive relationship of the concrete. The uniaxial tension stress-strain curve of concrete can be obtained by

$$
\begin{aligned}
& \sigma_{\mathrm{t}}=\left(1-d_{\mathrm{t}}\right) E_{\mathrm{c}} \varepsilon_{\mathrm{t}}, \\
& d_{\mathrm{t}}= \begin{cases}1-\rho_{\mathrm{t}}\left[1.2-0.2 x^{5}\right], & x \leq 1, \\
1-\frac{\rho_{\mathrm{t}}}{\alpha_{\mathrm{t}}(x-1)^{1.7}+x}, & x>1,\end{cases} \\
& x=\frac{\varepsilon_{\mathrm{t}}}{\varepsilon_{\mathrm{t}, \mathrm{r}}}, \\
& \rho_{\mathrm{t}}=\frac{f_{\mathrm{t}, \mathrm{r}}}{E_{\mathrm{c}} \varepsilon_{\mathrm{t}, \mathrm{r}}},
\end{aligned}
$$

where $\sigma_{\mathrm{t}}$ and $\varepsilon_{\mathrm{t}}$ are the tension stress and strain of concrete, respectively; $E_{c}$ is the elastic modulus of concrete $(\mathrm{MPa})$, for C50 and C30 concretes, $E_{\mathrm{c}}$ is $34,500 \mathrm{MPa}$ and $30,000 \mathrm{MPa}$, respectively; $d_{\mathrm{t}}$ is a damaged coefficient under uniaxial tension of the concrete; $\alpha_{\mathrm{t}}$ is a coefficient representing the falling rate of the stress-strain curve under uniaxial tension of the concrete, for C50 and C30 concretes, $\alpha_{\mathrm{t}}$ is 2.21 and 1.62, respectively; $f_{\mathrm{t}, \mathrm{r}}$ is the representative value of the uniaxial tension strength of the concrete, for C50 and C30 concretes, $f_{\mathrm{t}, \mathrm{r}}$ is $2.65 \mathrm{MPa}$ and $2.01 \mathrm{MPa}$, respectively; and $\varepsilon_{\mathrm{t}, \mathrm{r}}$ is the peak tension strain of the concrete corresponding to the representative value $f_{\mathrm{t}, \mathrm{r}}$, for C50 and C30 concretes, $\varepsilon_{\mathrm{t}, \mathrm{r}}$ is $110 \times 10^{-6}$ and $95 \times 10^{-6}$, respectively.

The uniaxial compression stress-strain curve of concrete can be obtained by

$$
\begin{aligned}
& \sigma_{\mathrm{c}}=\left(1-d_{\mathrm{c}}\right) E_{\mathrm{c}} \varepsilon_{\mathrm{c}}, \\
& d_{\mathrm{c}}= \begin{cases}1-\frac{\rho_{\mathrm{c}} n}{n-1+x}, & x \leq 1, \\
1-\frac{\rho_{\mathrm{c}}}{\alpha_{\mathrm{c}}(x-1)^{2}+x}, & x>1,\end{cases} \\
& \rho_{\mathrm{c}}=\frac{f_{\mathrm{c}, \mathrm{r}}}{E_{\mathrm{c}} \varepsilon_{\mathrm{c}, \mathrm{r}}} \\
& n=\frac{E_{\mathrm{c}} \varepsilon_{\mathrm{c}, \mathrm{r}}}{E_{\mathrm{c}} \varepsilon_{\mathrm{c}, \mathrm{r}}-f_{\mathrm{c}, \mathrm{r}}}, \\
& x=\frac{\varepsilon_{\mathrm{c}}}{\varepsilon_{\mathrm{c}, \mathrm{r}}}
\end{aligned}
$$

where $\sigma_{\mathrm{c}}$ and $\varepsilon_{\mathrm{c}}$ are the compression stress and strain of concrete, respectively; $d_{\mathrm{c}}$ is a damaged coefficient under uniaxial compression of the concrete; $\alpha_{c}$ is a coefficient representing the falling rate of the stress-strain curve under uniaxial compression of the concrete, for C50 and C30 concretes, $\alpha_{\mathrm{c}}$ is 1.45 and 0.75 , respectively; $f_{\mathrm{c}, \mathrm{r}}$ is the representative value of the uniaxial compression strength of concrete, for C50 and C30 concretes, $f_{c, r}$ is $32.4 \mathrm{MPa}$ and 20.1 $\mathrm{MPa}$, respectively; and $\varepsilon_{c, r}$ is the peak compression strain of the concrete corresponding to the representative value $f_{\mathrm{c}, \mathrm{r}}$, for C50 and C30 concretes, $\varepsilon_{\mathrm{c}, \mathrm{r}}$ is $1678 \times 10^{-6}$ and $1472 \times 10^{-6}$, respectively.

3.2. Interaction Simulation and Element Type. Figure 8 shows the interaction relationship and element type of members in the composite girder bridge. The interfacial relationship between the steel girder and the concrete deck is composed of normal contact and tangential bond slip. The bottom 


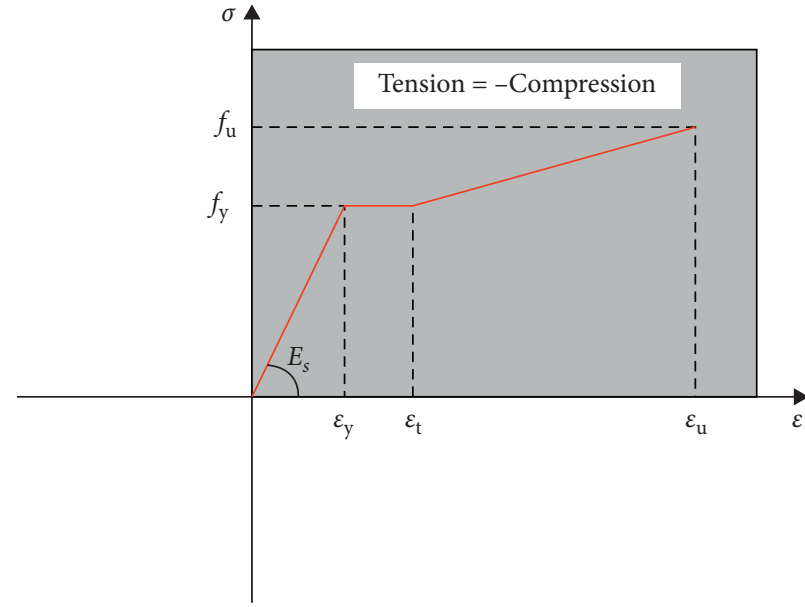

(a)

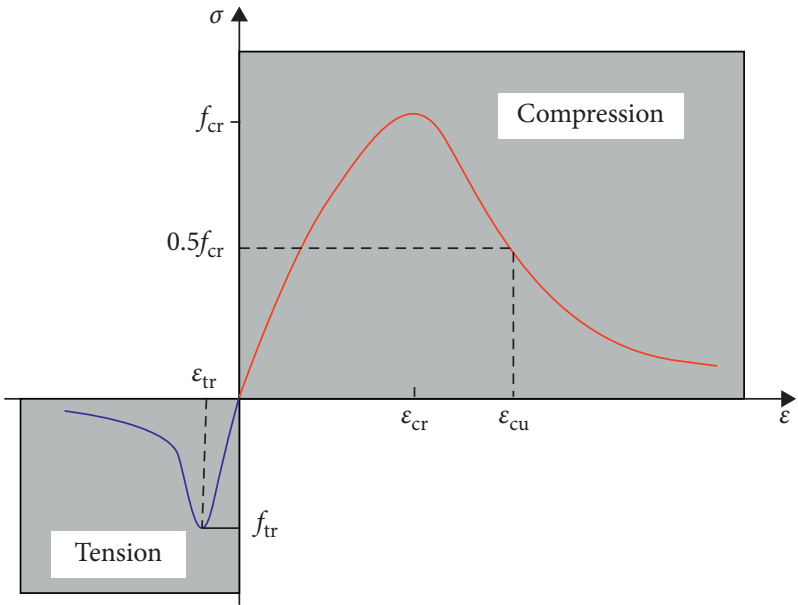

(b)

FIGURE 7: Constitutive relationship of materials: (a) steel and (b) concrete.

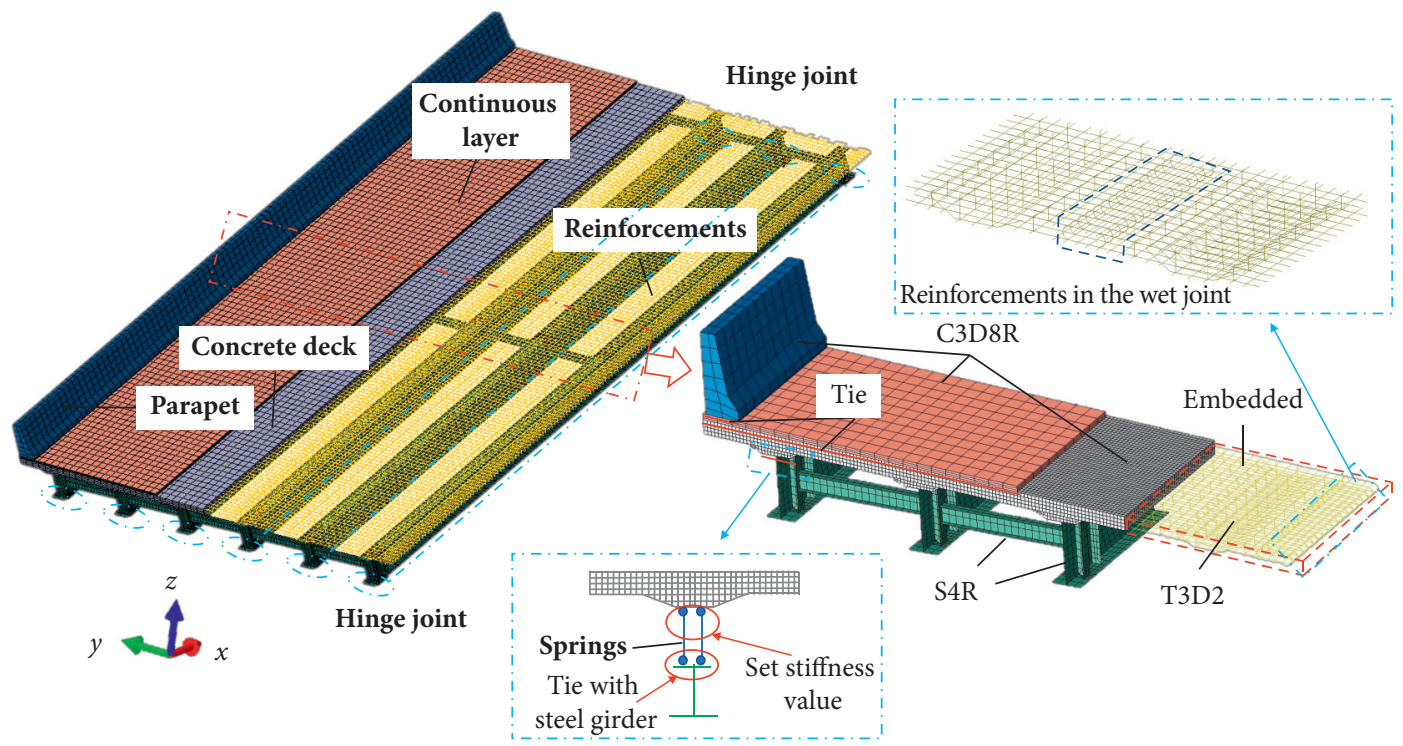

FIGURE 8: Interaction relationship and element type of members in the composite girder bridge.

surface of the deck was set as the main surface, while the top surface of the steel girder was set as the slave surface. The normal contact between steel girder and deck is "hard contact", which transferred the interfacial pressure. The tangential bond slip has been ignored because the longitudinal shear force of steel-concrete interface could be fully resisted by shear studs. The reinforcements were embedded into the concrete deck to simulate their contact relationship.

The steel girder and concrete deck are connected by shear studs, which are simulated by spring elements. The vertical stiffness could be obtained by Sutton et al.'s [37] modified equation, while the longitudinal and lateral stiffness of the springs could be calculated by

$$
k_{\mathrm{ss}}=13.0 d_{\mathrm{ss}} \sqrt{E_{\mathrm{c}} f_{\mathrm{ck}}}
$$

where $k_{\mathrm{ss}}$ is the shear stiffness of studs $(\mathrm{N} / \mathrm{mm}) ; d_{\mathrm{ss}}$ is the diameter of studs $(\mathrm{mm}) ; E_{\mathrm{c}}$ is the elastic modulus of the concrete (MPa); and $f_{\mathrm{ck}}$ is the standard value of the compression strength of the concrete $(\mathrm{MPa})$, usually takes $f_{\mathrm{ck}}=f_{\mathrm{c}, \mathrm{r}}$.

Steel girders, cross-beams, and stiffeners are all thinwalled members, whose thicknesses are much smaller than the dimension of other directions. Therefore, these members are simulated by the 4-node doubly curved thin or thick shell, reduced integration, hourglass control, finemembrane strains (S4R). The concrete deck, continuous layer, and parapets are simulated by 8 -node linear brick element, reduced integration, hourglass control element (C3D8R). The reinforcements are simulated by truss elements T3D2. 
3.3. Model Verification. Figure 9 shows the results of the calculated value by $\mathrm{FE}$ analysis and field test value of composite girder under the 4th step loading, including the strain and deflection of the steel girder, as shown in Figures 9(a) and 9(b), respectively, the longitudinal and lateral strain of the concrete deck, as shown in Figures 9(c) and 9(d), respectively, and strain of the cross-beam, as shown in Figure 9(e). Table 3 is the results of one-way analysis of variance between the values of the $\mathrm{FE}$ analysis and field test. The longitudinal strain of the bottom flange of the steel girder $\varepsilon_{\mathrm{sx}}$ was taken as an example for illustration. Under the significance level of 0.05 , the statistic value $F$ is less than the critical value $F_{0.05}$ (or the significance level $p$ is greater than 0.05), which indicates the single factor $\varepsilon_{\mathrm{sx}}$ is lightly affected by two different levels (the $\mathrm{FE}$ analysis and field test). Therefore, the difference of the $\varepsilon_{\mathrm{sx}}$ between the FE analysis and field test is small. For lateral bracing, only crossbeams 2\# and 3\# with the biggest strain difference between two levels were analysed. All single factors are lightly affected by two different levels (FE analysis and field test), except for the longitudinal strain of the concrete deck $\varepsilon_{\mathrm{cx}}\left(F>F_{0.05}\right.$ or $p<0.05)$. The reason is that the field test position of the $\varepsilon_{\mathrm{cx}}$ was close to the neutral axis of the composite section, and the small values of strain cause significant deviation between two different levels. In general, the FE analysis can be considered properly predicting the strain and deflection of the composite girder.

\section{Error Study}

Figure 10 shows the field test and linearly fitting longitudinal strain of the steel girder along girder depth under the fourstep loading. The bottom flange of the steel girder was set as vertical zero point (coordinate $z$ ). It shows that the longitudinal strain of the steel girder has a significant linear relationship along the girder depth, which indicates that the bridge is in an elastic working condition under field test loading. Moreover, the intercepts of fitted lines of the strain are in the depth about $100 \mathrm{~cm}$ to $120 \mathrm{~cm}$, which means that the position of the neutral axis of the composite girder can be regarded in this range.

Table 4 shows geometric properties of the composite girder. The theoretical position of the neutral axis of the composite girder is $86.74 \mathrm{~cm}$ from the bottom flange of the steel girder as shown in Case 3, and significantly different from the field test value. The reason for the difference may be related to the factors including the elastic modulus of the concrete deck, continuous layer, asphalt pavement, and parapets. When the elastic modulus of the concrete deck increases from $30,000 \mathrm{MPa}(\mathrm{C} 30)$ to $36,000 \mathrm{MPa}$ (C60), the neutral axis increases by about $3.0 \%$ along girder depth, and the bending stiffness of composite girder increases by about $4.6 \%$, as shown in Cases 1 to 4 . Therefore, the elastic modulus of the concrete deck has little effect on the bending stiffness of the composite girder and could be ignored. When considering the bending stiffness of the continuous layer and asphalt pavement, by comparing Case 5 and Cases 6 to 3, it was found that the neutral axis of the composite girder moves upward by about $8.3 \%$ and $0.3 \%$, respectively, while the bending stiffness increases by about $19.1 \%$ and $0.6 \%$, respectively. Thus, the continuous layer has great effect on the bending stiffness of the composite girder and could not be ignored, while the asphalt pavement could be ignored. Owing to the similar depth between parapets and composite girders, the position of the neutral axis of the composite girder is significantly affected by the parapet. By comparing Case 6 and Case 7, Case 8 and Case 9, Case 10 and Case 11, the neutral axis of the composite girder with parapets moves upward about $28.9 \%, 16.9 \%$, and $12.0 \%$ in the single girder, twin girders, and three girders, respectively, and the bending stiffness increases about 2.30, 1.32, and 0.92 times, respectively. Therefore, the parapet has great effect on the bending stiffness of the composite girder and could not be ignored.

For the purpose of comparison, a nondimensional parameter named ratio of bending stiffness error was defined as

$$
r_{\mathrm{bs}}=\frac{E I^{\prime}-E I_{0}}{E I_{0}}
$$

where $E I^{\prime}$ and $E I_{0}$ are the bending stiffness of the composite girder with parapets and without parapets, respectively and $h_{\mathrm{h}}$ and $h_{\mathrm{c}}$ are the depth of parapets and composite girders, respectively. It is obvious that the larger the $r_{\mathrm{bs}}$, the greater the effect of parapets on the composite girder.

Figure 11 shows the ratio of bending stiffness error. When $h_{\mathrm{h}} / h_{\mathrm{c}}$ equals $0.10, r_{\mathrm{bs}}$ is $10 \%, 6 \%$ and $4 \%$ for single girder (twin girders by symmetry), twin girders (four girders by symmetry) and three girders (six girders by symmetry), respectively, while $r_{\mathrm{bs}}$ is $26 \%, 14 \%$ and $9 \%$, respectively, when $h_{\mathrm{h}} / h_{\mathrm{c}}$ equals 0.20 . It was found that the effect of the parapet is decreasing with the number of main girders increasing, and the effect of the parapet can be ignored for single girder and twin girders only when the value of $h_{\mathrm{h}} / h_{\mathrm{c}}$ less than 0.10 , while $h_{\mathrm{h}} / h_{\mathrm{c}}$ should be less than 0.20 for three girders.

\section{Simplified Method of Calculating GDF by considering the Stiffness of Parapets}

According to the field test and theoretical results of the bending stiffness of the composite girder, the secondary members such as continuous layer and parapets had great effect on the bending stiffness of composite girders. Since the effect of the continuous layer on each steel girder was relatively uniform, this paper optimized the calculating method of the bridge GDF by only considering the stiffness of parapets.

\subsection{Optimization of Modified Eccentric Load Method}

\subsubsection{Assumption}

(i) No uplifting and slippage occur in the steel-concrete interface

(ii) The cross section remains rigid, and there are no distortion and local buckling

(iii) Ignoring the influence of asynchrony deformation between parapets and decks during construction 


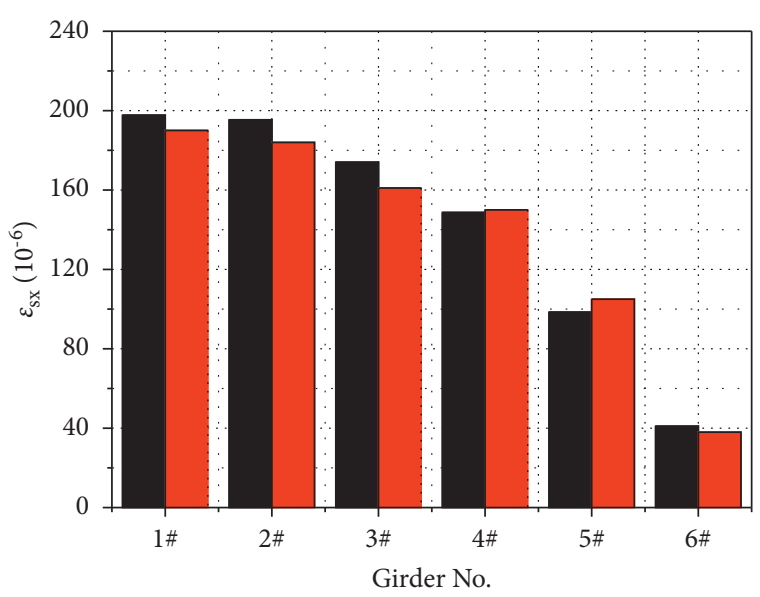

FE Analysis

Field Test

(a)

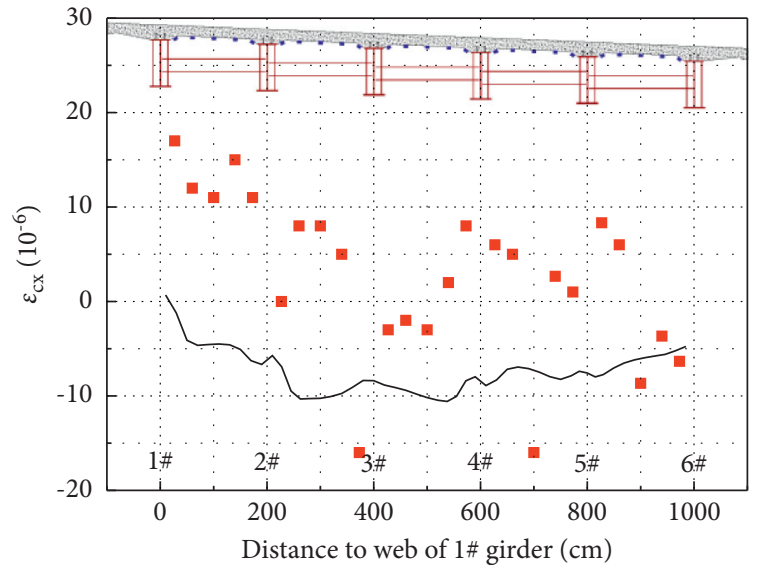

_ FE Analysis

- Field Test

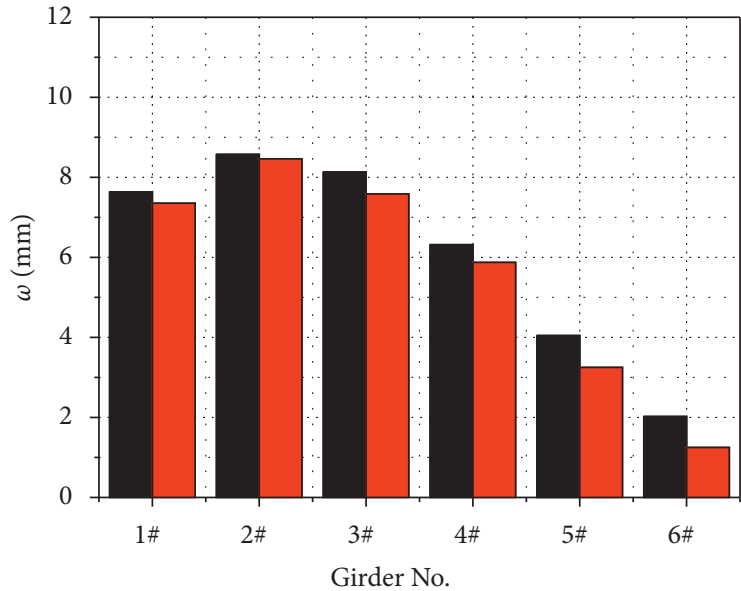

FE Analysis

Field Test

(b)

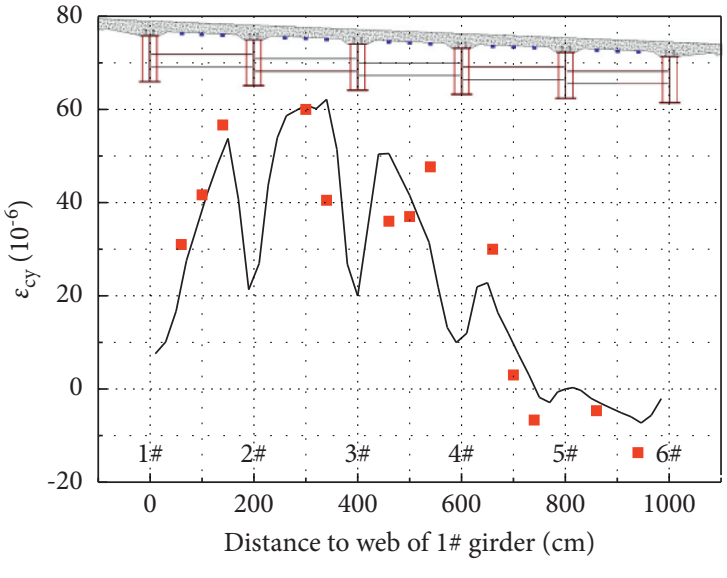

— FE Analysis

- Field Test

(c)

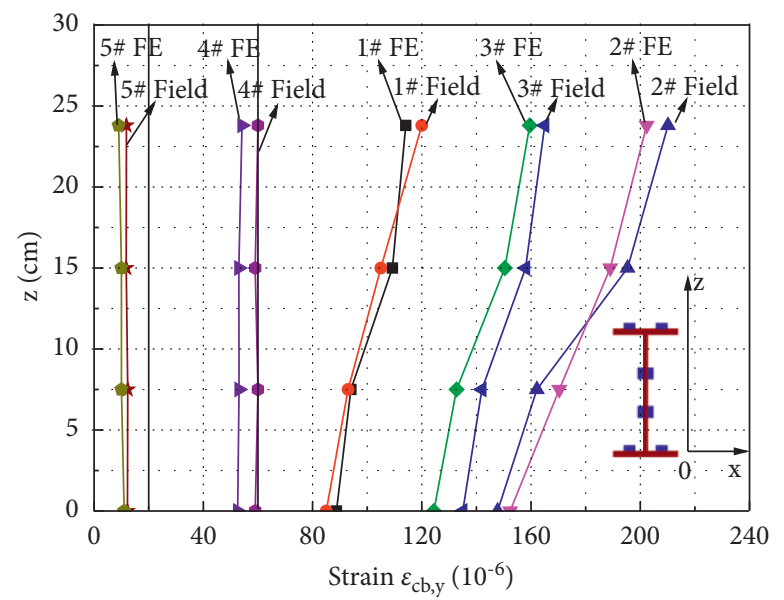

(e)

FIgURE 9: Results of the calculated value by FE analysis and the filed test value of composite girder under 4th step loading: (a) longitudinal strain of the bottom flange of the steel girder; (b) vertical deflection of the steel girder; (c) longitudinal strain of the bottom surface of the concrete deck; (d) lateral strain of the bottom surface of the concrete deck; (e) strain of the cross-beam. 
TABLE 3: One-way analysis of variance between the calculated value of FE analysis and the field test value.

\begin{tabular}{|c|c|c|c|c|c|c|c|}
\hline Position & Content & $\begin{array}{c}\text { Sum of squares of } \\
\text { deviations SS }\end{array}$ & $\begin{array}{l}\text { Degree of } \\
\text { freedom } d f\end{array}$ & $\begin{array}{c}\text { Mean } \\
\text { square MS }\end{array}$ & $\begin{array}{l}\text { Statistic } \\
\text { value } F\end{array}$ & $\begin{array}{c}\text { Critical } \\
\text { value } F_{0.05}\end{array}$ & $\begin{array}{l}\text { Significance } \\
\text { level } p\end{array}$ \\
\hline \multirow{2}{*}{$\begin{array}{l}\text { Bottom flange of } \\
\text { the steel girder }\end{array}$} & $\begin{array}{l}\text { Longitudinal strain } \\
\varepsilon_{\mathrm{sx}}\left(\times 10^{-6}\right)\end{array}$ & 61.64 & 1.00 & 61.64 & 0.02 & 4.97 & 0.90 \\
\hline & $\begin{array}{c}\text { Vertical deflection } \omega \\
(\mathrm{mm})\end{array}$ & 0.73 & 1.00 & 0.73 & 0.10 & 4.97 & 0.76 \\
\hline \multirow{2}{*}{$\begin{array}{l}\text { Bottom surface of } \\
\text { the deck }\end{array}$} & $\begin{array}{c}\text { Longitudinal strain } \\
\mathcal{E}_{\mathrm{cx}}\left(\times 10^{-6}\right)\end{array}$ & 1261.68 & 1.00 & 1261.68 & 31.82 & 4.04 & $8.82 \times 10^{-7}$ \\
\hline & $\begin{array}{l}\text { Lateral strain } \varepsilon_{c y} \\
\quad\left(\times 10^{-6}\right)\end{array}$ & 11.44 & 1.00 & 11.44 & 0.02 & 4.26 & 0.89 \\
\hline 2\# cross-beam & Strain $\varepsilon_{\mathrm{cs}, \mathrm{y}}\left(\times 10^{-6}\right)$ & 0.36 & 1.00 & 0.36 & 0 & 5.98 & 0.98 \\
\hline 3\# cross-beam & Strain $\varepsilon_{\mathrm{cs}, \mathrm{y}}\left(\times 10^{-6}\right)$ & 135.77 & 1.00 & 135.77 & 0.60 & 5.99 & 0.47 \\
\hline
\end{tabular}
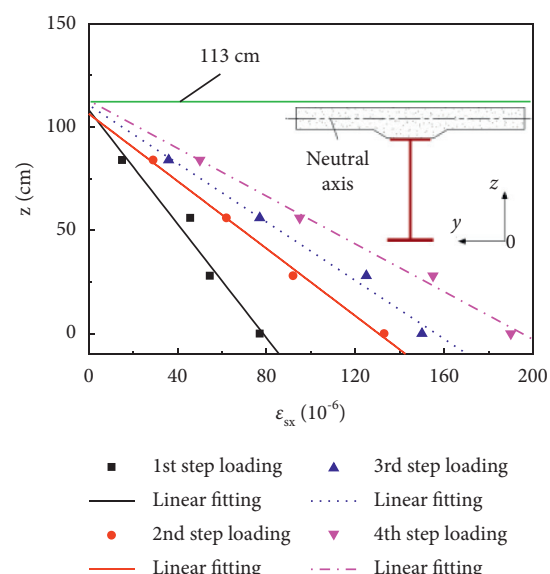

(a)

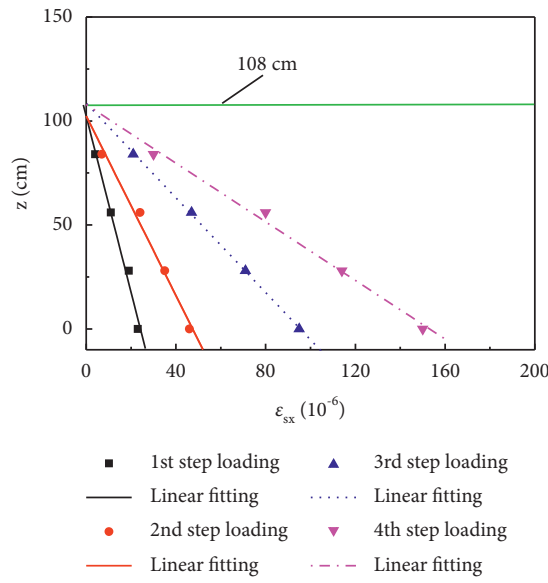

(d)
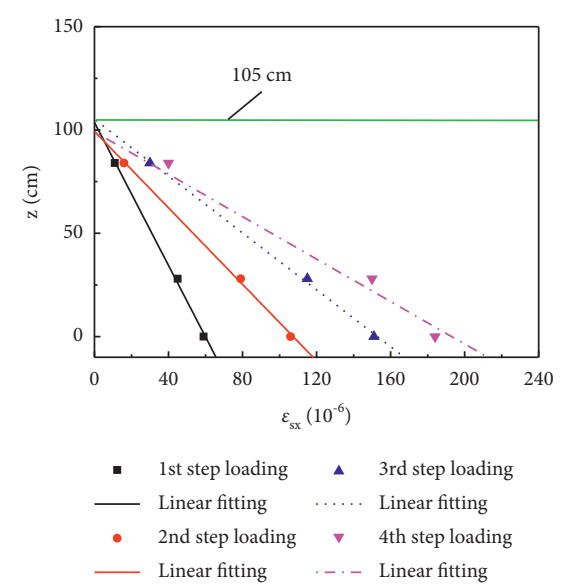

(b)

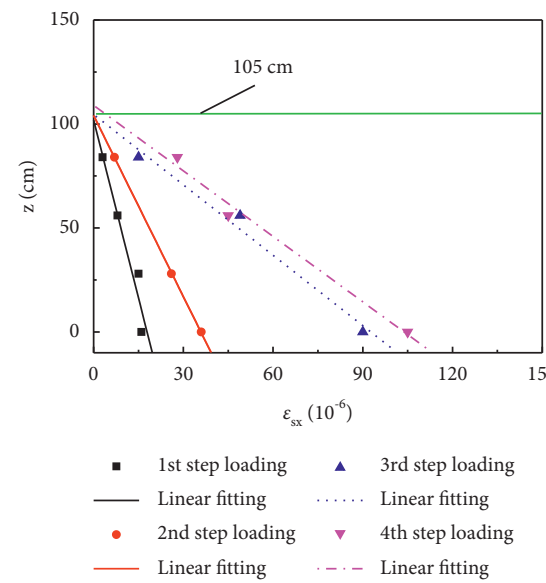

(e)

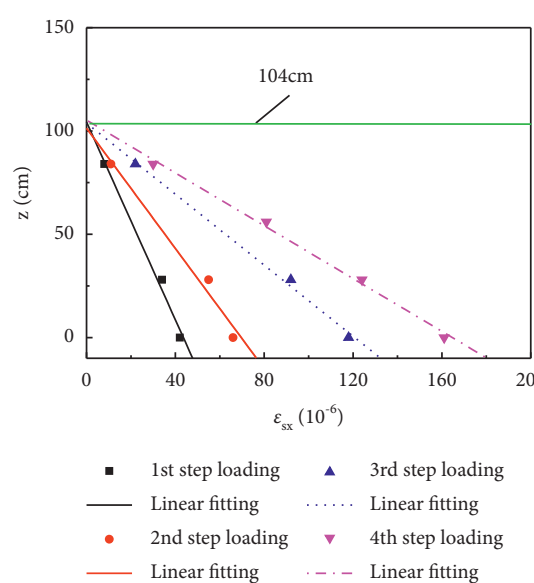

(c)

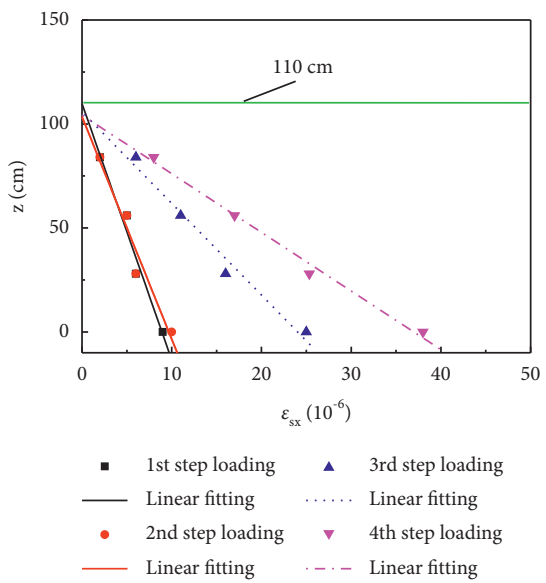

(f)

FiguRE 10: Longitudinal strain of the steel girder along girder depth: (a) 1\# girder; (b) 2\# girder; (c) 3\# girder; (d) 4\# girder; (e) 5\# girder; (f) 6\# girder.

(iv) Ignoring the influence of the transverse slope of the bridge, the cross section is symmetric about the centre line of the bridge

5.1.2. Centre Load $P=1$. Based on the assumption, the deflections of each main girder and parapet were the same under centre load and could be calculated by

$$
\omega_{1}=\omega_{2}=\cdots+\omega_{\mathrm{n}}=\omega_{1}^{\prime}=\omega_{2}^{\prime}=\omega_{m}^{\prime}
$$

where $\omega_{i}$ is the deflection of the main girder under centre load $(i=1,2,3, \ldots, n)$ and $\omega_{j}^{\prime}$ is the deflection of the parapet under centre load $(j=1,2,3, \ldots, m)$.

By converting the concrete deck into the steel deck according to the ratio of elastic modulus, the relationship 
TABLE 4: Geometric properties of composite girder.

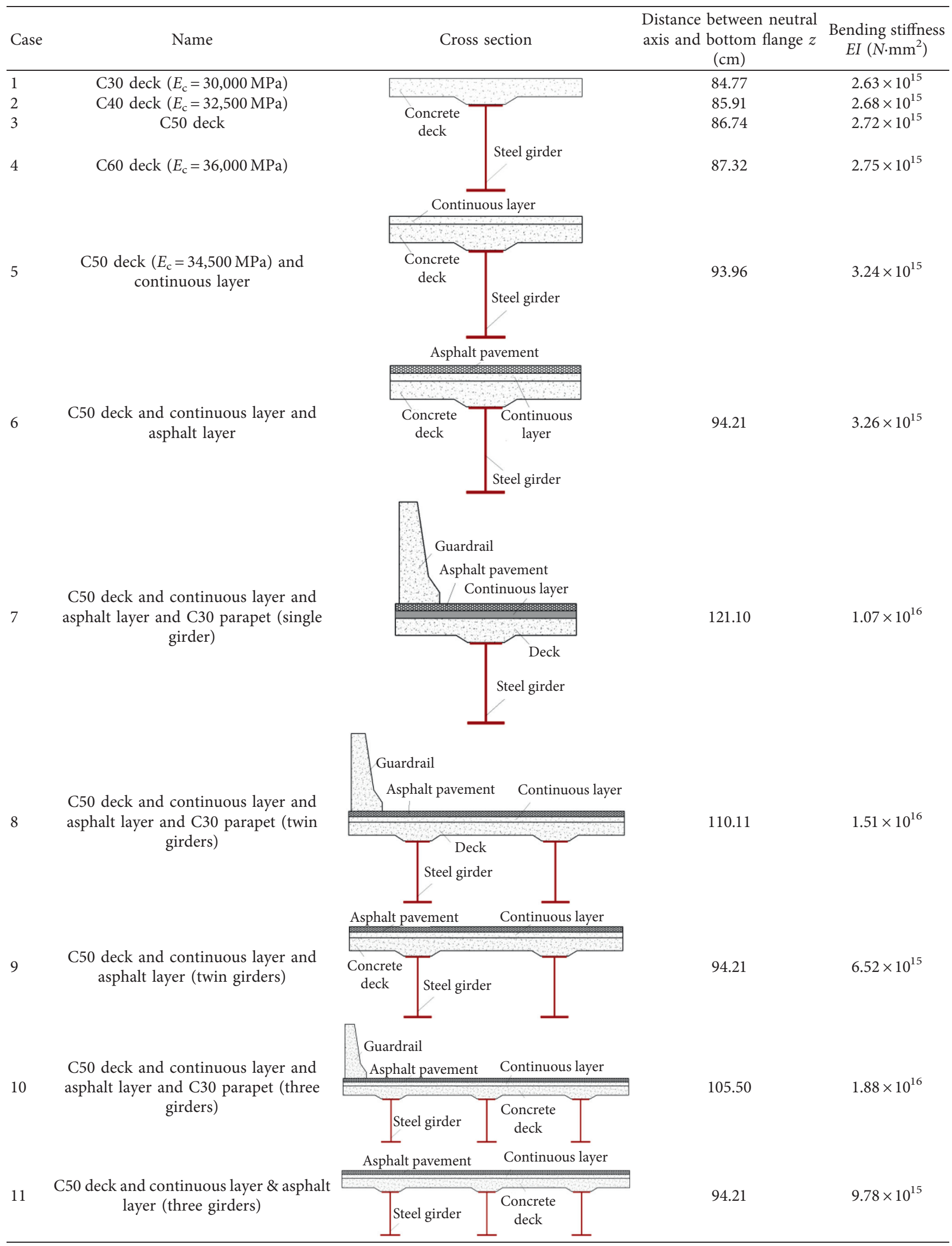




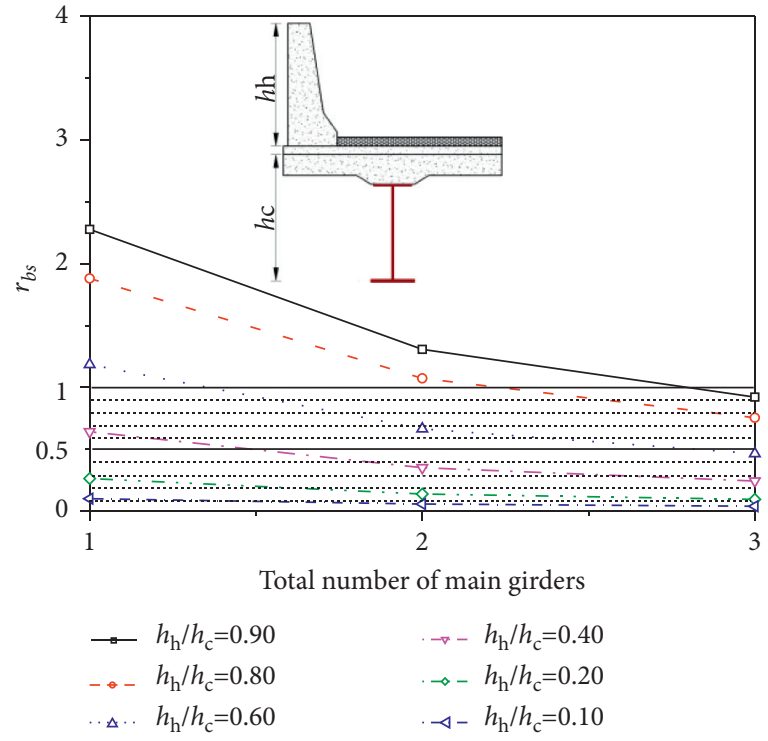

FIgure 11: The ratio of bending stiffness error.

between load and deflection of main girders and parapets in the midspan of a simply supported girder bridge are

$$
\begin{gathered}
\omega_{i}=\frac{R_{i} L^{3}}{48 E_{1} I_{i}}, \\
\omega_{j}^{\prime}=\frac{R_{j}^{\prime} L^{3}}{48 E_{2} I_{j}^{\prime}},
\end{gathered}
$$

where $E_{1}$ and $E_{2}$ are elastic modulus of main girders and parapets, respectively; $I_{i}$ and $I_{j}^{\prime}$ are inertia of moment of main girders and parapets, respectively; $R_{i}$ and $R_{j}^{\prime}$ are the distributed load by main girders and parapets, respectively; and $L$ is the span of the bridge.

Since $E_{1}, E_{2}$, and $L$ were constants, formulas (11) and (12) could be rewritten as

$$
\begin{aligned}
& R_{i}=\alpha \omega_{i} I_{i}, \\
& R_{j}^{\prime}=\alpha^{\prime} \omega_{j}^{\prime} I_{j}^{\prime},
\end{aligned}
$$

where $\alpha=48 E_{1} / L^{3}$ and $\alpha^{\prime}=48 E_{2} / L^{3}$.

According to the static equilibrium equation, formulas (13) and (14) could be added to obtain the following:

$$
\sum_{i=1}^{n} R_{i}+\sum_{j=1}^{m} R_{j}^{\prime}=\alpha \omega_{i} \sum_{i=1}^{n} I_{i}+\alpha^{\prime} \omega_{j}^{\prime} \sum_{j=1}^{m} I_{j}^{\prime}=1 .
$$

Substituting formula (10) into formula (15), the deflection of the main girder and the parapet could be calculated by

$$
\omega_{i}=\omega_{j}^{\prime}=\frac{1}{\alpha \sum_{i=1}^{n} I_{i}+\alpha^{\prime} \sum_{j=1}^{n} I_{j}^{\prime}} .
$$

Substituting formula (16) into formula (13), $R_{i}$ could be calculated by

$$
R_{i}=\frac{I_{i}}{\sum_{i=1}^{n} I_{i}+\lambda \sum_{j=1}^{n} I_{j}^{\prime \prime}},
$$

where $\lambda=\alpha^{\prime} / \alpha=E_{2} / E_{1}$

5.1.3. Eccentric Torque $M=1 \cdot e$. Under the action of eccentric torque $M=1 \cdot e$, a rotation angle $\varphi$ was produced as the cross section rotated around the centre point. The rotation angle of the main girder and parapet could be calculated by

$$
\begin{aligned}
& \omega_{i}^{\prime \prime}=a_{i} \tan \varphi, \\
& \omega_{j}^{\prime \prime}=a_{j}^{\prime} \tan \varphi,
\end{aligned}
$$

where $\omega_{i}^{\prime \prime}$ is the deflection of the main girder under the eccentric torque; $\omega_{j}^{\prime \prime}$ is the deflection of the parapet under the eccentric torque; $a_{i}$ is the distance between the main girder $i$ and bridge centre line; and $a_{j}^{\prime}$ is the distance between the parapet $j$ and bridge centre line.

Substituting formulas (18) and (19) into formulas (13) and (14), new equations are as follows:

$$
\begin{aligned}
& R_{i}^{\prime \prime}=\alpha a_{i} \tan \varphi I_{i}, \\
& R_{j}^{\prime \prime}=\alpha^{\prime} a_{j}^{\prime} \tan \varphi I_{j}^{\prime},
\end{aligned}
$$

where $R_{i}^{\prime \prime}$ and $R_{j}^{\prime \prime}$ are the distributed torque by the main girder and parapet, respectively.

Since $\alpha, \alpha^{\prime}$, and $\tan \varphi$ were constants, according to the static equilibrium equation, formulas (20) and (21) could be added to obtain

$$
\sum_{i=1}^{n} R_{j}^{\prime \prime} a_{i}+\sum_{j=1}^{m} R_{j}^{\prime \prime} a_{j}^{\prime}=\gamma \sum_{i=1}^{n} a_{i}^{2} I_{i}+\gamma^{\prime} \sum_{j=1}^{m} a_{j}^{\prime 2} I_{j}^{\prime}=1 \cdot e,
$$

where $\gamma=\alpha \tan \varphi$ and $\gamma^{\prime}=\alpha^{\prime} \tan \varphi$.

Solving formula (22), $\gamma$ could be calculated by

$$
\gamma=\frac{e}{\sum_{i=1}^{n} a_{i}^{2} I_{i}+\lambda \sum_{i=1}^{n} a_{j}^{\prime 2} I_{j}^{\prime}},
$$

where $e$ is the distance between the eccentric load and bridge centre line.

Substituting formula (23) into (20), $R_{i}^{\prime \prime}$ could be calculated by

$$
R_{i}^{\prime \prime}=\frac{e a_{i} I_{i}}{\sum_{i=1}^{n} a_{i}^{2} I_{i}+\lambda \sum_{j=1}^{m} a_{j}^{\prime 2} I_{j}^{\prime}}
$$

5.1.4. The Total Effect of the Eccentric Load on Each Main Girder. Adding formulas (17) and (24) and assuming the load was located on girder $k$, so the vertical coordinate value $R_{i k}$ of the influence line of girder $i$ could be calculated by

$$
R_{i k}=\frac{I_{i}}{\sum_{i=1}^{n} I_{i}+\lambda \sum_{j=1}^{m} I_{j}^{\prime}}+\frac{e a_{i} I_{i}}{\sum_{i=1}^{n} a_{i}^{2} I_{i}+\lambda \sum_{j=1}^{m} a_{j}^{\prime 2} I_{j}^{\prime}},
$$


According to the equilibrium equation and geometric relations, the torsional correction coefficient $\beta^{\prime}$ of the composite girder could also be deduced when considering the effect of torsional stiffness of the parapet as

$$
\beta^{\prime}=\frac{1}{1+l^{2} G_{1} \sum_{i=1}^{n} I_{T i} / 12 E_{1} \sum_{i=1}^{n} I_{i} a_{i}^{2}+l^{2} G_{2} \sum_{i=1}^{m} I_{T i}^{\prime} / 12 E_{2} \sum_{j=1}^{m} I_{j}^{\prime} a_{j}^{\prime 2}},
$$

where $G_{1}$ and $G_{2}$ are the shear modulus of the main girder and the parapet, respectively, and $I_{T i}$ and $I_{T i}^{\prime}$ are the torsional moment of inertia of the main girder and the parapet, respectively.

Finally, considering the torsional stiffness of the bridge, vertical coordinate value $\eta_{i k}$ of influence line of girder $i$ could be calculated by

$$
\eta_{i k}=\frac{I_{i}}{\sum_{i=1}^{n} I_{i}+\lambda \sum_{j=1}^{m} I_{j}^{\prime}} \pm \beta \prime \frac{e a_{i} I_{i}}{\sum_{i=1}^{n} a_{i}^{2} I_{i}+\lambda \sum_{i=1}^{m} a_{i}^{\prime 2} I_{j}^{\prime}},
$$

The symbols of equation were shown in Figure 12. Figure 13 shows the flowchart of calculating the GDF by the simplified method.

5.2. Comparison and Discussion. Figure 14 shows the most unfavorable condition of calculating the GDF for each girder. The GDF for 1 \# girder and 2 \# girder can be calculated by the results of the field test because the truck position of the field test was the most unfavorable condition for $1 \#$ girder and 2\# girder. By ignoring the transverse slope of the cross section, the GDF is equal for two girders which is symmetric about the centre line of the bridge. Table 5 shows the comparison results of the GDF calculated by different methods. According to the simplified method and FE analysis, compared to the GDF without considering the effect of the parapet, the GDF of exterior girder (1\# girder or 6\# girder) with the effect of the parapet decreased up to about $26.92 \%$ and $23.53 \%$, respectively, and the adjacent interior girder (2\# girder or 5\# girder) decreased up to about $15.22 \%$ and $12.77 \%$, respectively, while the middle girder (3\# girder or $4 \#$ girder) increased up to about $2.44 \%$ and $6.98 \%$, respectively. The GDF was almost same for two girders which was symmetric about the centre line of the bridge based on the FE analysis, so the reliability of the assumption of the simplified method was further verified. Comparing the GDF calculated by the AASHTO LRFD specifications, the GDF calculated by the simplified method decreased by about $30.77 \%$ in exterior girder and $41.30 \%$ in interior girder, respectively. The results indicate that the method of calculating the GDF without considering the effect of the parapet in AASHTO LRFD specifications is conservative. Moreover, the GDF calculated by the simplified method are basically close to the field test results, which indicates that the simplified method is relatively accurate in calculating the GDF.

Figure 15 shows the GDF with different height span ratio of the main girder $h_{\mathrm{c}} / L$. Under the constant height span ratio of the parapet $\left(h_{\mathrm{h}} / L=1 / 16.9\right)$, the $h_{\mathrm{c}} / L$ varied among $1 / 20,1 / 16.7$ (field test bridge), 1/14/, 1/12.5, and $1 / 11$, respectively. Compared to the GDF without considering the effect of the parapet, the GDF of 1 \# girder with the effect of the parapet decreased about $-24.31 \%,-23.53 \%$, $-22.15 \%,-20.52 \%$, and $-18.81 \%$, respectively, and the GDF of $2 \#$ girder decreased about $-10.95 \%,-10.42 \%,-5.12 \%$, $-4.10 \%$, and $-3.24 \%$, respectively, while the GDF of $3 \#$ girder increased by about 7.52\%, 6.98\%, 5.90\%, 5.39\%, and $4.89 \%$, respectively. According to the comparison results, under the constant $h_{\mathrm{h}} / L$, the effect of the parapet decreased with the increase of the $h_{\mathrm{c}} / L$. Moreover, the exterior girder (1\# girder) was more affected than the adjacent interior girder (2\# girder) and the middle girder (3\# girder). It also can be seen that the GDF increased with the increase of the $h_{\mathrm{c}} / L$. The GDF of the 1 \# girder with parapets and without parapets increased about $8.27 \%$ and $3.47 \%$ with the $h_{\mathrm{c}} / L$ increasing from $1 / 20$ to $1 / 11$, respectively, and the GDF of the $2 \#$ girder increased about $14.20 \%$ and $9.80 \%$, respectively, while the GDF of the $3 \#$ girder increased about $7.26 \%$ and $8.13 \%$, respectively.

In order to further investigate the effect of the parapet on the GDF of the bridge, GDFs of a six-girder bridge with different ratio of the parapet depth to the girder depth $h_{\mathrm{h}} /$ $h_{\mathrm{c}}$ were calculated, as shown in Figure 16. With the increase of the $h_{\mathrm{h}} / h_{\mathrm{c}}$, the GDF of the $1 \#$ girder and 2\# girder decreased almost linearly, while the GDF of the $3 \#$ girder increased almost linearly. When $h_{\mathrm{h}} / h_{\mathrm{c}}$ equals to 0.2 , compared to the GDF without considering the effect of the parapet, the GDF of 1\# girder and 2\# girder with the effect of the parapet decreased by about $-5.33 \%$ and $-3.83 \%$, respectively, while the GDF of $3 \#$ girder increased by about $0.80 \%$. When $h_{\mathrm{h}} / h_{\mathrm{c}}$ equals to 0.5 , the GDF of $1 \#$ girder and 2\# girder with the effect of the parapet decreased about $-9.47 \%$ and $-5.20 \%$, respectively, while the GDF of 3\# girder increased about $2.05 \%$. Therefore, the effect of the parapet on the GDF of the $1 \#$ girder and 2\# girder in the six-girder bridge could be ignored when $h_{\mathrm{h}} /$ $h_{\mathrm{c}}$ is less than 0.2 and 0.5 , respectively. As for $3 \#$ girder, the effect of the parapet on the GDF could be ignored because the GDF of 3\# girder with the effect of the parapet increased only about $4.76 \%$ when $h_{\mathrm{h}} / h_{\mathrm{c}}$ equals to 1.0 . It also can be seen that the GDF of each girder tended to be the same with the increase of $h_{\mathrm{h}} / h_{\mathrm{c}}$, meaning that the stress distribution in each girder of the bridge gradually became uniform.

Designers and researchers mainly pay attention to the GDF of the exterior girder (1\# girder) and adjacent interior girder (2\# girder) of the bridge because the maximum GDF is usually at the exterior girder or adjacent interior girder. Based on the maximum GDF, girders of the bridge were usually designed in the same dimension. Although the stiffness of the parapet was usually not considered in the 


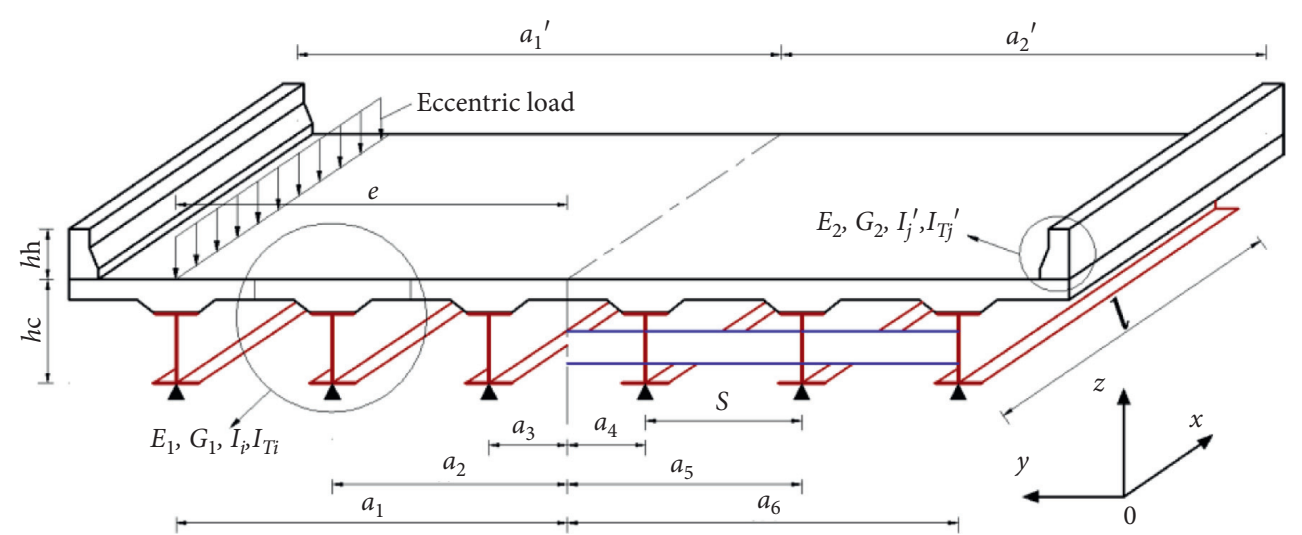

FIGURE 12: Symbols of equations.

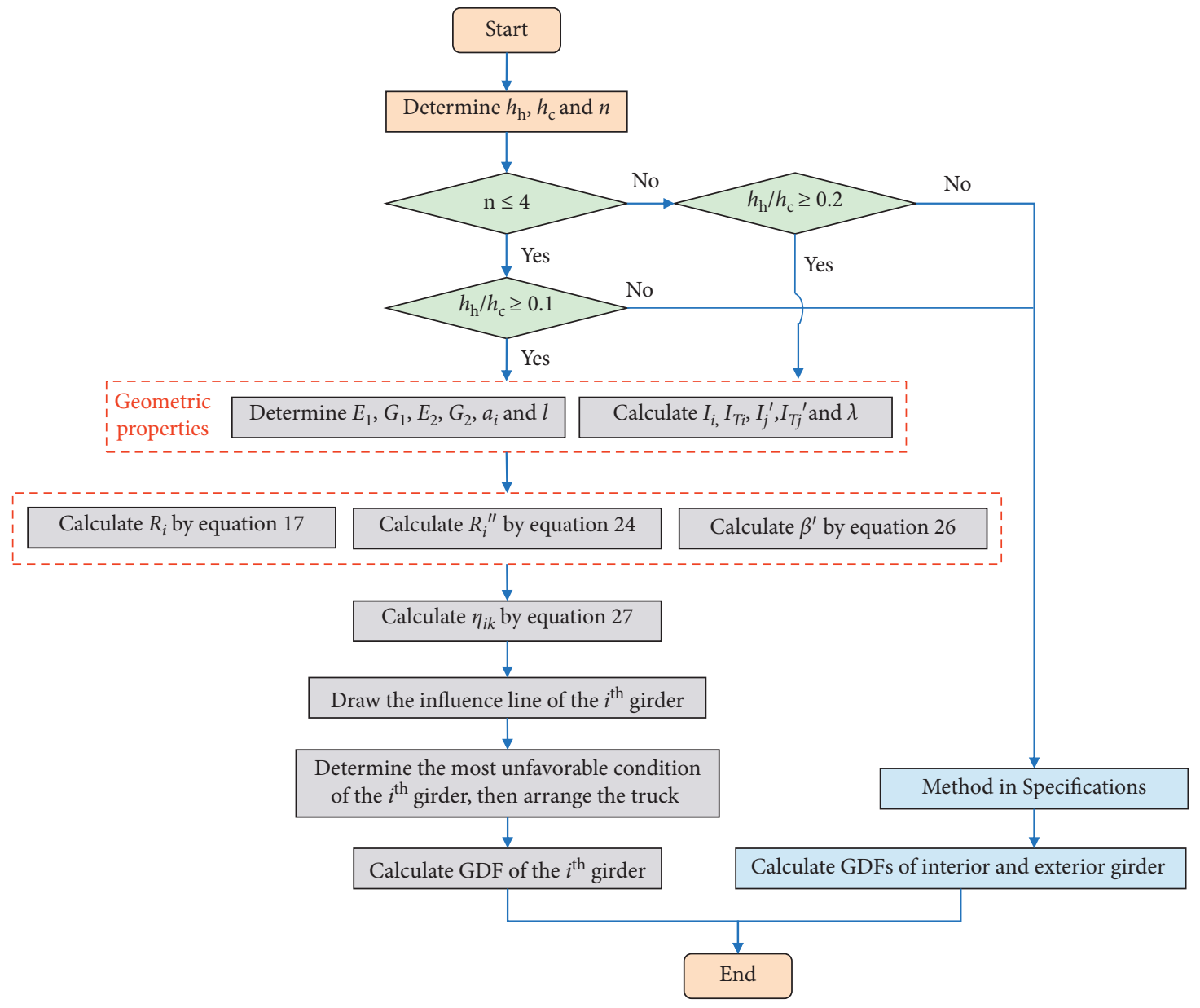

Simplified method

AASHTO LRFD

FIgURE 13: Flowchart of calculating the GDF by the simplified method.

design, the reserved strength contributed by parapets to the bridge could be estimated by the simplified method conveniently, and the parapet ensured that the bridge had a certain overload capacity. In addition, it was helpful for better understanding the force or stress distribution of the bridge. 


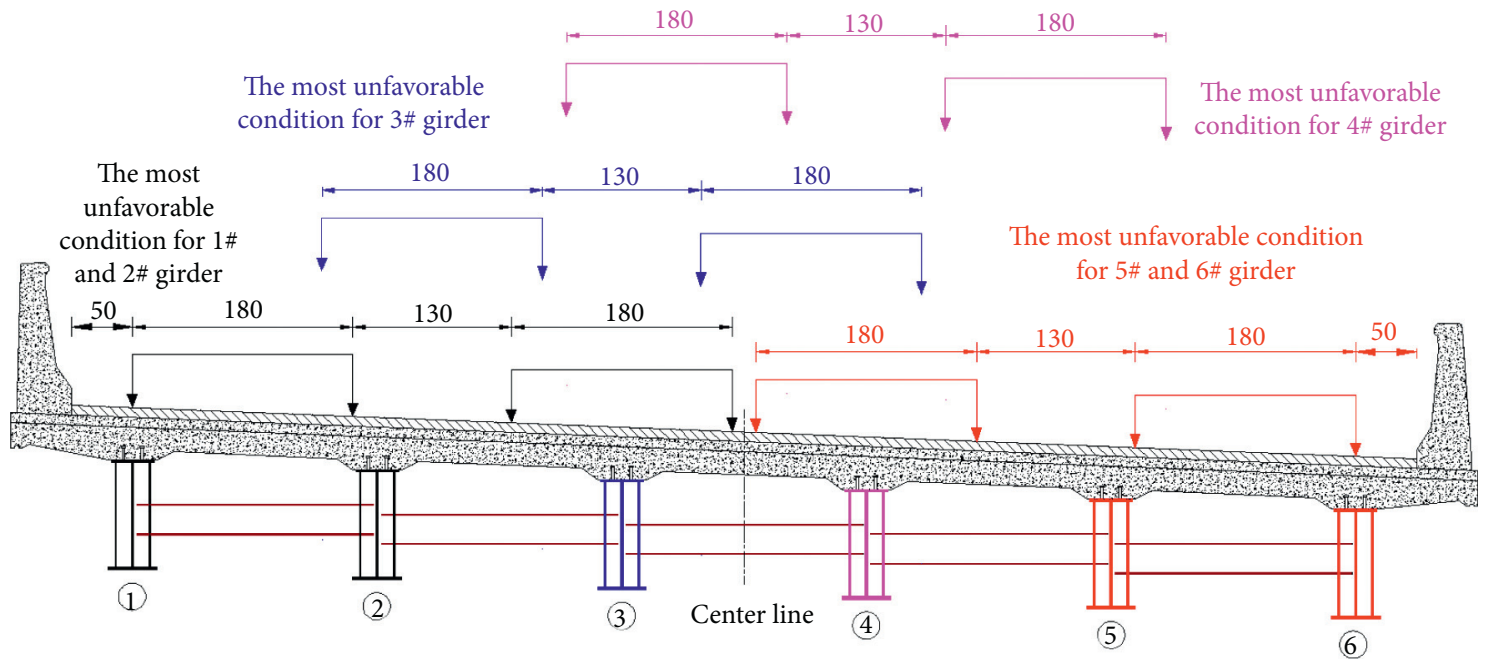

Figure 14: The most unfavorable condition of calculating the GDF for each girder.

TABle 5: Comparisons of the girder distribution factor.

\begin{tabular}{|c|c|c|c|c|c|c|c|c|c|}
\hline \multirow{2}{*}{$\begin{array}{l}\text { Girder } \\
\text { no. }\end{array}$} & \multirow{2}{*}{$\begin{array}{c}\text { Modified } \\
\text { eccentric } \\
\text { load } \\
\text { method } \\
\text { Without } \\
\text { parapet } \\
\text { (1) }\end{array}$} & \multirow{2}{*}{$\begin{array}{l}\text { Simplified } \\
\text { method } \\
\text { With } \\
\text { parapet (2) }\end{array}$} & \multicolumn{4}{|c|}{ FE analysis } & \multirow{2}{*}{$\begin{array}{c}\text { Field } \\
\text { test } \\
\text { With } \\
\text { parapet } \\
\text { (5) }\end{array}$} & $\begin{array}{c}\text { AASHTO } \\
\text { LRFD } \\
2017\end{array}$ & \multirow{2}{*}{$($ (2) $-(6) /(2) \times 100 \%$} \\
\hline & & & & $\begin{array}{l}\text { Without } \\
\text { parapet } \\
\text { (3) }\end{array}$ & $\begin{array}{l}\text { With } \\
\text { parapet } \\
\text { (4) }\end{array}$ & & & $\begin{array}{l}\text { Without } \\
\text { parapet (6) }\end{array}$ & \\
\hline $1 \#$ & 0.66 & 0.52 & -26.92 & 0.63 & 0.51 & -23.53 & 0.49 & 0.68 & -30.77 \\
\hline $2 \#$ & 0.53 & 0.46 & -15.22 & 0.53 & 0.48 & -10.42 & 0.47 & 0.65 & -41.30 \\
\hline $3 \#$ & 0.40 & 0.41 & 2.44 & 0.40 & 0.42 & 4.76 & - & - & - \\
\hline $4 \#$ & 0.40 & 0.41 & 2.44 & 0.40 & 0.43 & 6.98 & - & - & - \\
\hline $5 \#$ & 0.53 & 0.46 & -15.22 & 0.53 & 0.47 & -12.77 & - & 0.65 & -41.30 \\
\hline $6 \#$ & 0.66 & 0.52 & -26.92 & 0.62 & 0.52 & -19.23 & - & 0.68 & -30.77 \\
\hline
\end{tabular}
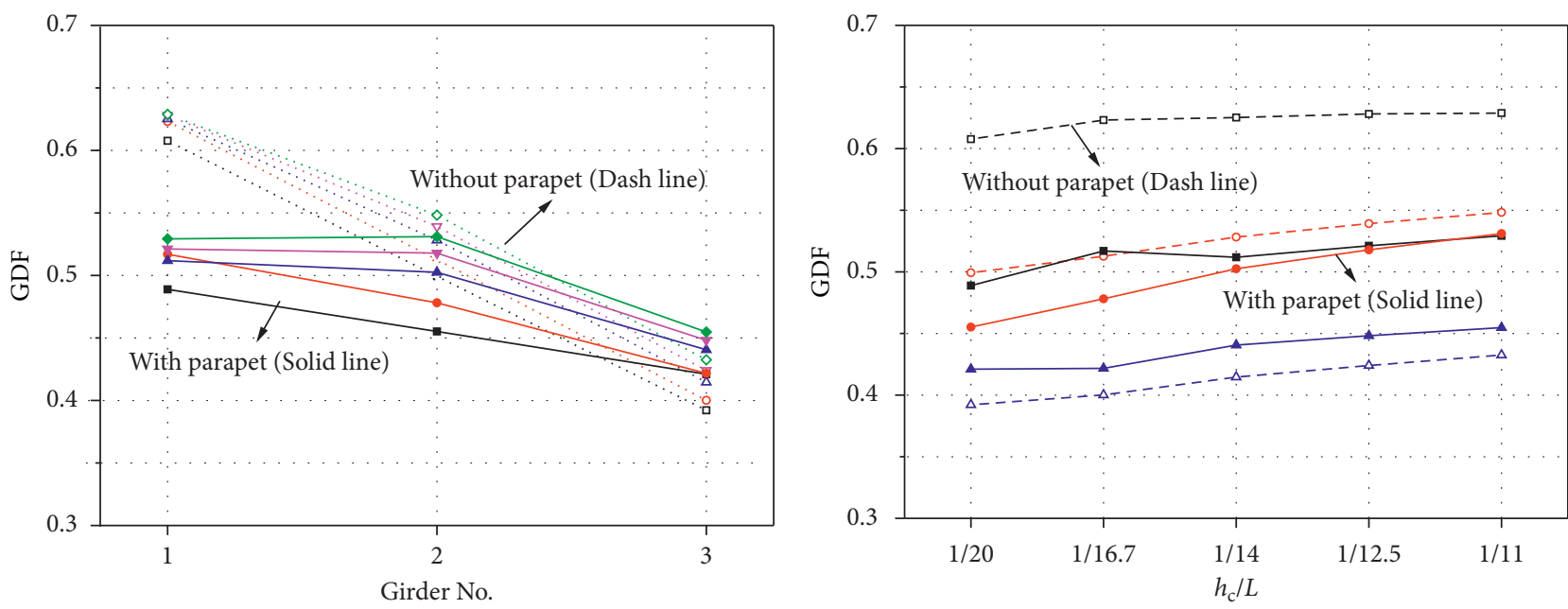

$$
\begin{aligned}
& \longrightarrow h_{\mathrm{c}} / L=1 / 20.0 \\
& \longrightarrow h_{\mathrm{c}} / L=1 / 14.0 \\
& \rightarrow h_{\mathrm{c}} / L=1 / 11.0 \\
& \rightarrow h_{\mathrm{c}} / L=1 / 16.7 \\
& \rightarrow h_{\mathrm{c}} / L=1 / 12.5
\end{aligned}
$$$$
\text { ... } h_{\mathrm{c}} / L=1 / 20.0
$$$$
\text { ... } h_{\mathrm{c}} / L=1 / 14.0
$$$$
\text { \&.. } h_{\mathrm{c}} / L=1 / 11.0
$$$$
\text { ... } h_{\mathrm{c}} / L=1 / 16 \text {.7 }
$$$$
\text { จ.. } h_{\mathrm{c}} / L=1 / 12.5
$$

(a)

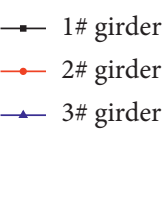

a... 1\# girder

- ... 2\# girder

४.. 3\# girder

FIGURE 15: The GDF with different height span ratio of the main girder: (a) the GDF varies with the girder no and (b) the GDF varies with the hight span ratio $(\mathrm{h})_{\mathrm{c}} /(\mathrm{L})$. 


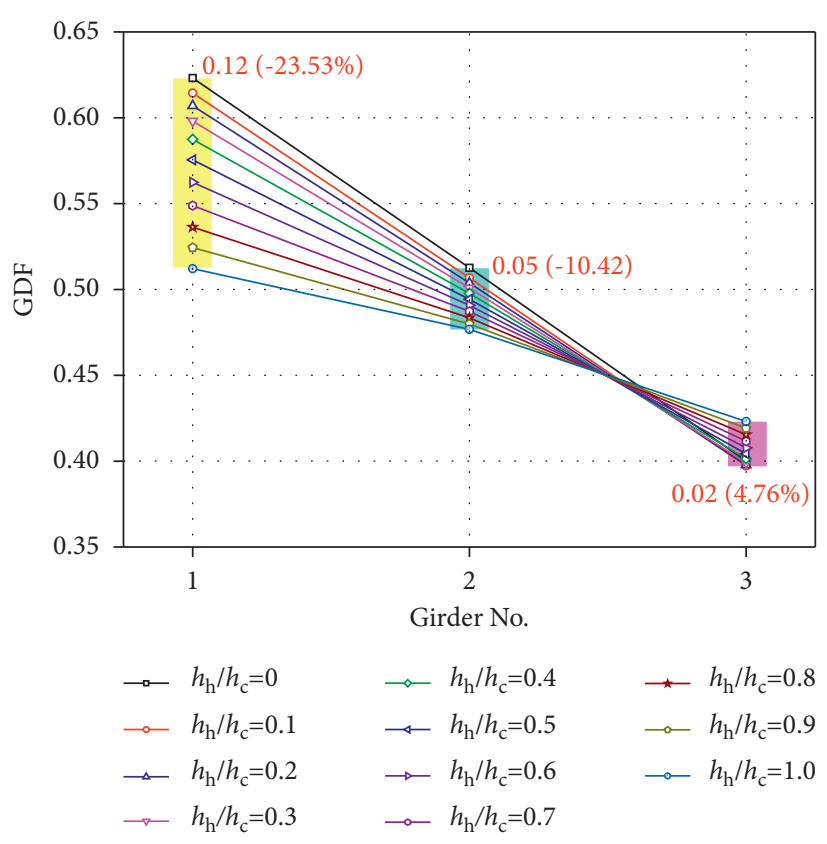

(a)

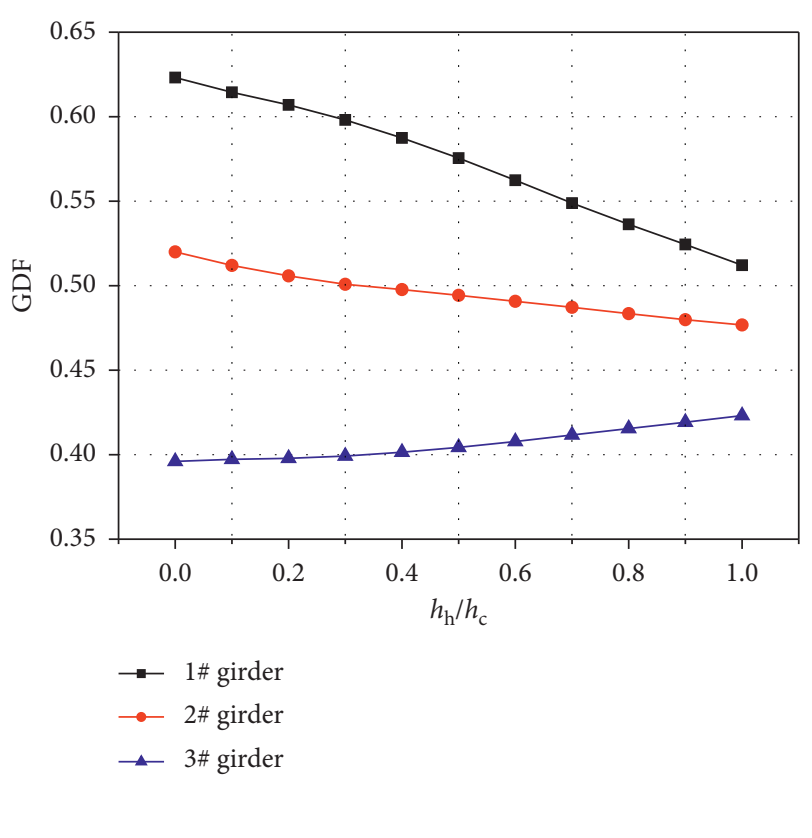

(b)

Figure 16: The GDF with different ratio of the parapet depth to the girder depth: (a) the GDF varies with the girder no. and (b) the GDF varies with the ratio of girder depth to parapet depth $(\mathrm{h})_{\mathrm{h}} /(\mathrm{h})_{\mathrm{c}}$.

\section{Conclusion}

This paper developed a simplified method to estimate the effect of parapets on the GDF. The GDF was also obtained by the field test and FE analysis in the investigation. The following conclusions can be obtained:

(1) The bending stiffness of the composite girder EI increased by about $4.6 \%$ when the elastic modulus of the concrete deck varied from $30,000 \mathrm{MPa}$ to $36,000 \mathrm{MPa}$. Compared to the EI without the parapet, continuous layer, and asphalt pavement, the $E I$ with the parapet, continuous layer, and asphalt pavement increased by about $92 \%, 19.1 \%$, and $0.6 \%$, respectively. The results indicate that the parapet and continuous layer had a great influence on the EI and could not be ignored, while the asphalt pavement and the variation of the elastic modulus of the concrete deck had little influence on the EI and could be ignored.

(2) According to the simplified method and FE analysis, compared to the GDF without considering the effect of the parapet, the GDF of the exterior girder (1\# girder) with the effect of the parapet decreased up to about $26.92 \%$ and $23.53 \%$, respectively, and the adjacent interior girder (2\# girder) decreased up to about $15.22 \%$ and $12.77 \%$, respectively, while the middle girder ( $3 \#$ girder) increased by about $2.44 \%$ and $6.98 \%$, respectively. Comparing the GDF calculated by the AASHTO LRFD specifications, the GDF calculated by the simplified method decreased about $30.77 \%$ in the exterior girder and $41.30 \%$ in the interior girder, respectively. The results indicate that the method of calculating the GDF without considering the effect of the parapet in AASHTO LRFD specifications is conservative.

(3) The GDF of the bridge increased with the increase of the height span ratio of the main girder $h_{\mathrm{c}} / L$. The GDF of the exterior girder with parapets and without parapets increased by about $8.27 \%$ and $3.47 \%$ with the $h_{\mathrm{c}} / L$ increasing from $1 / 20$ to $1 / 11$, respectively, and the GDF of the interior girder increased by about $14.20 \%$ and $9.80 \%$, respectively, while the GDF of the middle girder increased by about $7.26 \%$ and $8.13 \%$, respectively.

(4) The effect of the parapet on the GDF of the exterior girder and interior girder in the six-girder bridge could be ignored when the ratio of the parapet depth to the girder depth $h_{\mathrm{h}} / h_{\mathrm{c}}$ is less than 0.2 and 0.5 , respectively. As for the middle girder, the effect of the parapet on the GDF could be ignored because the GDF of the middle girder with the effect of the parapet increased only about $4.76 \%$ when $h_{\mathrm{h}} / h_{\mathrm{c}}$ equals 1.0 .

(5) It indicates that the proposed simplified method considering the bending stiffness of the parapet was relatively accurate because the GDF calculated by the simplified method was basically close to the field test results. The stiffness of the parapet was usually not considered in the design, but the reserved strength of the bridge contributed by the parapet could be estimated by the simplified method conveniently. The parapet also ensured that the bridge had a certain overload capacity. 


\section{Data Availability}

The data used to support the findings of this study are available from the corresponding author upon request.

\section{Conflicts of Interest}

The authors declare no conflicts of interest.

\section{Acknowledgments}

The authors gratefully acknowledge the financial support given by the Special Fund for Basic Scientific Research of Central College of Chang'an University (grant no. 300102218407) and the Science and Technology Projects of Department of Transport of Shaanxi Province of China (grant nos. 17-14K and 16-29K).

\section{References}

[1] AASHTO, AASHTO Standard Specifications for Highway Bridges, American Association of State Highway and Transportation Officials (AASHTO), Washington, D.C.USA, 1996.

[2] G. K. Michaelson, Live Load Distribution Factors for Exterior Girders in Steel I-Girder Bridges, West Virginia University, Morgantown, WV, USA, 2010.

[3] H. Zhang, D. Huang, and T.-L. Wang, "Lateral load distribution in curved steel I-girder bridges," Journal of Bridge Engineering, vol. 10, no. 3, pp. 281-290, 2005.

[4] N. M. Newmark, C. P. Siess, and W. M. Peckham, Studies of Slab and Beam Highway Bridges: Part II, Tests of Simple-Span Skew I-Beam Bridges, University of Illinois at Urbana Champaign Library, Urbana, IL, USA, 1948.

[5] W. W. Sanders and H. A. Elleby, Distribution of Wheel Loads on Highway Bridges, Vol. 83, NCHRP Report, Washington, D.C., USA, 1970.

[6] B. Bakht, M. S. Cheung, and T. S. Aziz, "Application of a simplified method of calculating longitudinal moments to the Ontario highway bridge design code," Canadian Journal of Civil Engineering, vol. 6, no. 1, pp. 36-50, 1979.

[7] T. Zokaie, R. A. Imbsen, and T. A. Osterkamp, "Distribution of wheel loads on highway bridges," Transportation Research Record, vol. 1290, pp. 119-126, 1991.

[8] T. Zokaie, "AASHTO-LRFD live load distribution specifications," Journal of Bridge Engineering, vol. 5, no. 2, pp. 131-138, 2000.

[9] AASHTO, AASHTO LRFD Bridge Design Specification, American Association of State Highway and Transportation Officials (AASHTO), Washington, DC, USA, 2017.

[10] K. Phuvoravan, W. Chung, J. Liu, and E. D. Sotelino, "Simplified live load distribution factor equation for steel girder bridges," Transportation Research Record, vol. 1892, pp. 88-97, 2004.

[11] X. S. Huo, E. P. Wasserman, and P. Zhu, "Simplified method of lateral distribution of live load moment," Journal of Bridge Engineering, vol. 9, no. 4, pp. 382-390, 2004.

[12] X. S. Huo, E. P. Wasserman, and R. A. Iqbal, "Simplified method for calculating lateral distribution factors for live load shear," Journal of Bridge Engineering, vol. 10, no. 5, pp. 544-554, 2005.

[13] X. S. Huo and Q. Zhang, "Effect of skewness on the distribution of live load reaction at piers of skewed continuous bridges," Journal of Bridge Engineering, vol. 13, no. 1, pp. 110-114, 2008.

[14] C. P. Henis and J. O. Jin, "Live load distribution on braced curved I-girders," Journal of Structure Engineering, vol. 110, no. 3, pp. 523-530, 1984.

[15] R. L. Brockenbrough, "Distribution factors for curved I-girder bridges," Journal of Structural Engineering, vol. 112, no. 10, pp. 2200-2215, 1986.

[16] M. A. Khaleel and R. Y. Itani, "Live-load moments for continuous skew bridges," Journal of Structural Engineering, vol. 116, no. 9, pp. 2361-2373, 1990.

[17] A. G. Bishara, M. C. Liu, and N. D. Ei-Ali, "Wheel load distribution on simply supported skew I-beam composite bridges," Journal of Structural Engineering, vol. 119, no. 2, pp. 399-419, 1990.

[18] P. J. Barr, M. O. Eberhard, and J. F. Stanton, "Live-load distribution factors in prestressed concrete girder bridges," Journal of Bridge Engineering, vol. 6, no. 7, pp. 298-306, 2001.

[19] C. S. Cai, "Discussion on AASHTO LRFD load distribution factors for slab-on-girder bridges," Practice Periodical on Structural Design and Construction, vol. 10, no. 3, pp. 171-176, 2005.

[20] C. S. Cai, “"Discussion of "discussion on AASHTO LRFD load distribution factors for slab-on-girder bridges", " Practice Periodical on Structural Design and Construction, vol. 11, no. 4, pp. 247-248, 2006.

[21] K. N. Smith and I. Mikelsteins, "Load distribution in edge stiffened slab and slab-on-girder bridge decks," Canadian Journal of Civil Engineering, vol. 15, no. 6, pp. 977-983, 1988.

[22] M. E. Mabsout, K. M. Tarhini, G. R. Frederick, and M. Kobrosly, "Influence of sidewalks and railings on wheel load distribution in steel girder bridges," Journal of Bridge Engineering, vol. 2, no. 3, pp. 88-96, 1997.

[23] M. G. Barker, "Quantifying field-test behavior for rating steel girder bridges," Journal of Bridge Engineering, vol. 6, no. 4, pp. 254-261, 2001.

[24] C. D. Eamon and A. S. Nowak, "Effects of edge-stiffening elements and diaphragms on bridge resistance and load distribution," Journal of Bridge Engineering, vol. 7, no. 5, pp. 258-266, 2002.

[25] C. D. Eamon and A. S. Nowak, "Effect of secondary elements on bridge structural system reliability considering moment capacity," Structural Safety, vol. 26, no. 1, pp. 29-47, 2004.

[26] S. Conner and X. S. Huo, "Influence of parapets and aspect ratio on live-load distribution," Journal of Bridge Engineering, vol. 11, no. 2, pp. 188-196, 2006.

[27] W. Chung, J. Liu, and E. D. Sotelino, "Influence of secondary elements and deck cracking on the lateral load distribution of steel girder bridges," Journal of Bridge Engineering, vol. 11, no. 2, pp. 178-187, 2006.

[28] M. R. Roddenberry, J. Chipperfield, and K. S. Tawfiq, "Effect of secondary elements on load distribution in prestressed bridge girders," Structures Congress, pp. 215-226, 2011.

[29] M. R. Roddenberry, D. Kuhn, and R. G. Tindale, "Barrier effect on transverse load distribution for prestressed concrete segmental box girder bridges," Journal of Bridge Engineering, vol. 21, no. 6, pp. 1-11, 2016.

[30] N. O. Akinci, J. Liu, and M. D. Bowman, "Parapet strength and contribution to live-load response for superload passages," Journal of Bridge Engineering, vol. 13, no. 1, pp. 55-63, 2008.

[31] N. O. Akinci, J. Liu, and M. D. Bowman, "Spring analogy to predict the 3-D live load response of slab-on-girder bridges," Engineering Structures, vol. 56, pp. 1049-1057, 2013. 
[32] JTG/T J21-01-2015, Load Test Methods for Highway Bridge, Chang'an University, Xi'an, China, 2016.

[33] D. K. Harris, "Assessment of flexural lateral load distribution methodologies for stringer bridges," Engineering Structures, vol. 32, no. 11, pp. 3443-3451, 2010.

[34] C. J. Waldron, T. E. Cousins, A. J. Nassar, and J. P. Gomez, "Demonstration of use of high-performance lightweight concrete in bridge superstructure in Virginia," Journal of Performance of Constructed Facilities, vol. 19, no. 2, pp. 146-154, 2005.

[35] J. Eom and A. S. Nowak, "Live load distribution for steel girder bridges," Journal of Bridge Engineering, vol. 6, no. 6, pp. 489-497, 2001.

[36] J. M. Stallings and C. H. Yoo, "Tests and rsspan steel bridges," Journal of Structural Engineering, vol. 119, no. 7, pp. 21502168, 1993.

[37] J. P. Sutton, J. M. Mouras, V. A. Samaras, E. B. Williamson, and K. H. Frank, "Strength and ductility of shear studs under tensile loading," Journal of Bridge Engineering, vol. 19, no. 2, pp. 245-253, 2014. 